\title{
Comparative Studies of Some Novel Cu(II) Polymeric Complexes Derived from Cyanoacetylhydrazine (CAH; L). The Role of Solvents Used on the Structure and Geometry of the Isolated $\mathrm{Cu}^{2+}$ Complexes
}

\author{
Mohsen M. Mostafa \\ Chemistry Departments, Faculty of Science, Mansoura University, Mansoura, Egypt \\ Email: amohsenmostafa@Yahoo.com
}

How to cite this paper: Mostafa, M.M. (2021) Comparative Studies of Some Novel $\mathrm{Cu}(\mathrm{II})$ Polymeric Complexes Derived from Cyanoacetylhydrazine (CAH; L). The Role of Solvents Used on the Structure and Geometry of the Isolated $\mathrm{Cu}^{2+}$ Complexes. Open Journal of Inorganic Chemistry, 11, 111-130. https://doi.org/10.4236/ojic.2021.114008

Received: August 6, 2021

Accepted: October 17, 2021

Published: October 20, 2021

Copyright $\odot 2021$ by author(s) and Scientific Research Publishing Inc. This work is licensed under the Creative Commons Attribution International License (CC BY 4.0).

http://creativecommons.org/licenses/by/4.0/

\begin{abstract}
Novel polymeric $\mathrm{Cu}^{2+}$ complexes derived from the reaction of cyanoacetylhydrazine $(\mathrm{CAH} ; \mathrm{L})$ with $\mathrm{CuCl}_{2} \cdot 2 \mathrm{H}_{2} \mathrm{O}$ in different solvents were synthesized and characterized. The isolated solid polymeric complexes were investigated using modern conventional physicochemical and spectral (IR, ${ }^{1} \mathrm{H}-\mathrm{NMR}$, UV-Vis. ESR, Raman), magnetic and thermal studies. The results revealed that CAH behaves in different ways towards the coordination of the $\mathrm{Cu}^{2+}$ ion. The promotion of solvents to the cyano group was discussed on the basis of the solvent and the $\mathrm{Cu}^{2+}$ ion used. Magnetic and spectral studies suggest octahedral geometry is proposed for the $\mathrm{Cu}^{2+}$ complexes. EPR studies indicate the existence of polymeric complexes depending on the results of $g$-values. The results suggest that the number of copper atoms ranges from three to twelve atoms. The molecular modeling is drawn and some chemical characteristics are calculated such as chemical reactivity and energy components are investigated between the different types of the ligands.
\end{abstract}

\section{Keywords}

Polymeric Cu(II) Complexes, ESR Studies, Cyanoacetylhydrazine, DFT Studies

\section{Introduction}

The class of organic compounds contains the functional active group (-CONHNH$\left.{ }_{2}\right)$ is known as hydrazides. Great interest in the chemistry of hydrazides is explained 
by diversity and at times by the originality of their properties. Hydrazides have acquired great importance due to their multifarious biological properties including antibacterial, antifungal, anti-inflammatory and anti-tuberculosis activities [1] [2] [3] [4] [5]. CAH is considered as an intermediate for the synthesis of a variety of heterocyclic compounds. The $\beta$-functional nitrile [6] [7] [8] [9] moiety in the compound is a favorable unit for addition followed by cyclization or via cyclo-addition with numerous reagents providing heterocyclic compounds having different ring sizes with one or several heteroatoms that are interesting as pharmaceuticals [10] [11], herbicides [12], antibacterial agents [13], and dyes [14] [15]. Also, hydrazides find wide applications as drugs, chemical preservers for plants, manufacturing polymers, glues and many other purposes [16]. Mostafa et al. [17] reported the reactions of cyanoacetylhydrazine (SCH, L) with some metal ions $\left(\mathrm{Co}^{2+}, \mathrm{Ni}^{2+}, \mathrm{Cu}^{2+}, \mathrm{Zn}^{2+}, \mathrm{Cd}^{2+}\right.$ and $\left.\mathrm{UO}_{2}^{2+}\right)$ in $\mathrm{EtOH}$. Three types of complexes with the general formulae, $\left[\mathrm{M}(\mathrm{L})_{2} \mathrm{X}_{2}\right] \mathrm{S}\left(\mathrm{M}=\mathrm{Co}^{2+}, \mathrm{Ni}^{2+}\right.$ or $\mathrm{Cd}^{2+} ; \mathrm{X}=$ $\mathrm{Cl}^{-}$or $\mathrm{Ac}^{-} ; \mathrm{S}=\mathrm{EtOH}$ or $\left(\mathrm{H}_{2} \mathrm{O}\right),\left[\mathrm{M}(\mathrm{L}-\mathrm{H})_{2}\right] \mathrm{S}\left(\mathrm{M}=\mathrm{Co}^{2+}, \mathrm{Cu}^{2+}, \mathrm{Zn}^{2+}, \mathrm{UO}_{2}^{2+} ; \mathrm{S}\right.$ $\left(\mathrm{H}_{2} \mathrm{O}\right)$ and $\left[\mathrm{Hg}(\mathrm{L}-\mathrm{H}) \mathrm{Cl} \cdot \mathrm{H}_{2} \mathrm{O}\right]$, were isolated and characterized. On the other hand, the reaction of $\mathrm{Fe}^{3+}$ and $\mathrm{Cu}^{2+}$ chloride or bromide with $\mathrm{L}$ in aqueous ethanolic solution is accompanied by the reduction to $\mathrm{Fe}^{2+}$ and $\mathrm{Cu}^{+}$, respectively [17]. The synthesis and characterization of some metal complexes containing salicylaldehyde cyanoacetylhydrazone (SCH), 1-salicyl-hydrazo-3-imino-3-isopropoxy propionic acid hydrazide (SIPPH) and 1-salicylhydrazo-3-imino-3-tertbutoxy propionic acid hydrazide (SIBPH) were reported [18]. The complexes were characterized using elemental analyses, spectral ( ${ }^{1} \mathrm{H}-\mathrm{NMR}$, IR, visible), conductance and magnetic measurements. IR spectral data suggest that the ligands (SCH, SIPPH and SIBPH) coordinated in tridentate and/or bidentate manners with different modes of bonding toward the metal ions. Moreover, a polymeric structure via an imido group for some $\mathrm{Cu}^{2+}$ complexes is discussed. Finally, the ${ }^{1} \mathrm{H}-\mathrm{NMR}$ spectra of the ligands and some diamagnetic complexes are discussed. The reactions of salicylaldehyde with a suspension of cyanoacetylhy-drazine and/or malonic acid amido-hydrazide complexes in aqueous EtOH solutions afford novel complexes [19]. The structures of the isolated complexes have been confirmed by conventional physical and chemical measurements. The absence or the weakness of the cyano group in the IR spectra of all complexes, except those of $\mathrm{Co}^{2+}$ and $\mathrm{Ni}^{2+}$ complexes, suggests the promotion of $\mathrm{H}_{2} \mathrm{O}$ to the cyano group forming amido group [19]. In this paper, the use of the $\mathrm{Cu}^{2+}$ salts which act as a catalyst in the synthesis of the polymeric complexes helps to a great extent the promotion of the solvents to the cyano group.

The goal of our study is to investigate the role of the solvents on the reaction products of $\mathrm{CAH}$ in the presence of $\mathrm{Cu}^{2+}$ ions. The isolated polymeric complexes were characterized using different physical, chemical, thermal, spectral and magnetic methods. The results of EPR were studied and the values of $g_{\|}, g_{\perp}, g_{\odot} K_{\|}$, $K_{\perp}, a^{2}$ and $B^{2}$ were calculated. Also, the structures of ligands were elucidated using molecular modeling. Thermal analyses were carried to determine the number of solvents inside or outside the coordination sphere. 


\section{Experimental}

\subsection{Instrumentation and Materials}

All chemicals were of AR quality and used without further purification. Elemental analyses (C, H, N) were carried out by Perkin-Elmer CHN 2400 analyzer based on catharometric detection after combustion. Chloride and copper contents were determined by the micronalysis centre, CNRS service central of analysis at Vernaison (France). TGA analysis was performed using Dupont-950 thermogravimetric analyser in $\mathrm{KBr}$ discs were recorded on a Mattson 5000 FTIR (Mansoura University) and Perkin-Elmer in the range $20^{\circ} \mathrm{C}-800^{\circ} \mathrm{C}$ and recorded on a TGA-50 Shimadzu TGA analyzer at a heating rate of $15^{\circ} \mathrm{C} / \mathrm{min}$ and nitrogen flow rate of $20 \mathrm{ml} / \mathrm{min}$. IR spectra $\left(4000-200 \mathrm{~cm}^{-1}\right)$ in Perkin-Elmer $883 \mathrm{IF}$ spectrophotometers (France). Electronic spectra were recorded on a Unicam UV-Vis, V-100 and Perkin-Elmer Lambda 9 spectrophotometers. The magnetic measurements were carried out at room temperature $\left(25^{\circ} \mathrm{C}\right)$ on a Sherwood magnetic balance. Diamagnetic corrections were calculated using Pascal's constants [20]. ${ }^{1} \mathrm{H}-\mathrm{NMR}$ measurements in $\mathrm{d}_{6}$-DMSO at room temperature were carried out on Jeol-90Q Fourier transform (400 MHz) and Bruker AM 250 spectrometers. The results of EPR measurements were obtained using Bruker EPR 200 provided with Hewlett-Packard frequency meter (modulation frequency, $100 \mathrm{KHz}$; microwave power; $20 \mathrm{~mW}$; field modulation intensity; $3.2 \mathrm{Gpp}$ and gain, $\left.2.5 \times 10^{5}\right)$.

\subsection{Synthesis of Cyanoacetylhydrazine (CAH; $\mathrm{L}$ )}

CAH ( $\mathrm{L}$ ) was synthesized by adding equivalent amounts of hydrazine hydrate (3 $\mathrm{ml} ; 0.1 \mathrm{~mol})$ drop by drop with constant stirring to ethyl cyanoacetate $(11 \mathrm{ml}, 0.1$ $\mathrm{mol}$ ) in EtOH for $1.5 \mathrm{~h}$ at room temperature $\left(25^{\circ} \mathrm{C}\right)$. The reaction mixture was cooled in ice bath till a white solid product was obtained. The precipitate was filtered off, recrystallized from absolute ethanol (yield: 89\%) and finally dried in a desiccator over $\mathrm{P}_{4} \mathrm{O}_{10}$. The purity was checked by elemental analyses, TLC and spectra data (IR, ${ }^{1} \mathrm{H}-\mathrm{NMR}$, Vis-Uv, Raman and TGA). The uncorrected melting point of the product was found to be $\left(108^{\circ} \mathrm{C}-110^{\circ} \mathrm{C}\right)$.

\subsection{Synthesis of $\mathrm{Cu}^{2+}$ Complexes}

Twelve novel polymeric $\mathrm{Cu}^{2+}$ complexes were isolated and characterized with the aid of elemental analyses, physical and spectroscopic methods. The different complexes were synthesized by mixing in each reaction equivalent amounts of $\mathrm{L}$ $(0.2 \mathrm{M})$ in different solvents $\left(\mathrm{H}_{2} \mathrm{O}, \mathrm{MeOH}, \mathrm{EtOH}, \mathrm{n}\right.$-proponal, n-butanol and $\mathrm{n}$-pentanol) and $\mathrm{CuCl}_{2} \cdot 2 \mathrm{H}_{2} \mathrm{O}(0.1 \mathrm{M})$ in EtOH. The reaction mixtures were refluxed on a hot plate for a time depending on the solvent used. The polymeric complexes formed in the flask were poured in a beaker followed by scratching the reaction mixture in each experiment by a glass rod till solid precipitates were formed as fine powders. The complexes were filtered off and washed several times with the solvent used in the preparation of the complexes followed by 
washing with diethyl ether. The isolated products were preserved in a vacuum desiccator over $\mathrm{P}_{4} \mathrm{O}_{10}$. The analyses of the isolated solid complexes together with some physical data are depicted in Table 1 . The complexes are stable in air and soluble in polar solvents. The numbers of the copper ions in the isolated complexes were estimated from the data of elemental analyses as well as results of EPR and found to be in the range from $3-12$ atoms. The electronic spectra and the magnetic moments of the $\mathrm{Cu}(\mathrm{II})$ complexes are recorded in Table 2. The data of the polymeric complexes are summarized as follow:

Complex (1) $\left(\mathrm{C}_{11} \mathrm{H}_{23} \mathrm{Cl}_{2} \mathrm{~N}_{9} \mathrm{O}_{6} \mathrm{Cu}_{3}\right)$; yield: $70 \%$; color: dark brown powder; $\mathrm{MP}>$ $270^{\circ} \mathrm{C}$, M.Wt: $638.9 ; \mu_{\text {eff }}(1.95 \mathrm{BM})$ and conductivity (DMSO): $6 \Omega^{-1} \cdot \mathrm{cm}^{2} \cdot \mathrm{mol}^{-1}$.

Complex (2) $\left(\mathrm{C}_{36} \mathrm{H}_{71} \mathrm{Cl}_{14} \mathrm{~N}_{27} \mathrm{O}_{18} \mathrm{Cu}_{12}\right)$; yield: 83\%; color: yellowish-green powder; MP > 270 ${ }^{\circ}$ C, M.Wt: $2400.0 ; \mu_{\text {eff }}\left(0.91 \mathrm{BM}\right.$ ); conductivity (DMSO): $9 \Omega^{-1} \cdot \mathrm{cm}^{2} \cdot \mathrm{mol}^{-1}$.

Complex (3) $\left(\mathrm{C}_{31} \mathrm{H}_{75} \mathrm{Cl}_{7} \mathrm{~N}_{24} \mathrm{O}_{23} \mathrm{Cu}_{8}\right)$; yield: 76\%; color: brown powder; $\mathrm{MP}>$ $270^{\circ} \mathrm{C}$; M.Wt. 1908.6; $\mu_{\text {eff }}(1.24 \mathrm{BM})$; conductivity (DMSO): $13 \Omega^{-1} \cdot \mathrm{cm}^{2} \cdot \mathrm{mol}^{-1}$.

Complex (4) $\left(\mathrm{C}_{19} \mathrm{H}_{38} \mathrm{Cl}_{7} \mathrm{~N}_{15} \mathrm{O}_{8} \mathrm{Cu}_{4}\right)$; yield: $90 \%$; color: kaki-green powder; $\mathrm{MP}>$ $270^{\circ} \mathrm{C}$; M.Wt: $1107 ; \mu_{\text {eff }}(1.02 \mathrm{BM})$; conductivity (DMSO): $13 \Omega^{-1} \cdot \mathrm{cm}^{2} \cdot \mathrm{mol}^{-1}$.

Table 1. Analytical and physical data of the ligands and its $\mathrm{Cu}^{2+}$ complexes.

\begin{tabular}{|c|c|c|c|c|c|c|c|c|c|}
\hline \multirow{2}{*}{ No. } & \multirow{2}{*}{ Chemical formula } & \multirow{2}{*}{ (M. Wt) } & \multicolumn{7}{|c|}{ \% Found (Calcd.) } \\
\hline & & & $\mathrm{C}$ & $\mathrm{H}$ & $\mathrm{Cu}$ & $\mathrm{Cl}$ & $\mathbf{N}$ & Solvent & Solvent used in synthesis \\
\hline 1 & $\mathrm{C}_{11} \mathrm{H}_{23} \mathrm{Cl}_{2} \mathrm{~N}_{9} \mathrm{O}_{6} \mathrm{Cu}_{3}$ & 638.9 & $\begin{array}{c}20.7 \\
(21.1)\end{array}$ & $\begin{array}{c}3.6 \\
(3.1)\end{array}$ & $\begin{array}{c}29.8 \\
(29.0)\end{array}$ & $\begin{array}{c}11.1 \\
(11.0)\end{array}$ & $\begin{array}{c}19.7 \\
(18.6)\end{array}$ & $\begin{array}{c}5.7 \\
(5.6)\end{array}$ & $\mathrm{H}_{2} \mathrm{O}$ \\
\hline 2 & $\mathrm{C}_{36} \mathrm{H}_{71} \mathrm{Cl}_{14} \mathrm{~N}_{27} \mathrm{O}_{18} \mathrm{Cu}_{12}$ & 2400.0 & $\begin{array}{c}18.0 \\
(17.8)\end{array}$ & $2.7(3.0)$ & $\begin{array}{c}31.8 \\
(31.9)\end{array}$ & $\begin{array}{c}20.7 \\
(20.4)\end{array}$ & $\begin{array}{c}15.8 \\
(15.6)\end{array}$ & --- & $\mathrm{MeOH}$ \\
\hline 3 & $\mathrm{C}_{31} \mathrm{H}_{75} \mathrm{Cl}_{7} \mathrm{~N}_{24} \mathrm{O}_{23} \mathrm{Cu}_{8}$ & 1908.6 & $\begin{array}{c}19.5 \\
(18.8)\end{array}$ & $\begin{array}{c}4.0 \\
(3.3)\end{array}$ & $\begin{array}{c}26.6 \\
(26.4)\end{array}$ & $\begin{array}{c}12.9 \\
(13.0)\end{array}$ & $\begin{array}{c}17.2 \\
(17.6)\end{array}$ & $\begin{array}{c}7.7 \\
(7.7)\end{array}$ & $\mathrm{H}_{2} \mathrm{O}+\mathrm{MeOH}$ \\
\hline 4 & $\mathrm{C}_{19} \mathrm{H}_{38} \mathrm{Cl}_{7} \mathrm{~N}_{15} \mathrm{O}_{8} \mathrm{Cu}_{4}$ & 1107.0 & $\begin{array}{c}19.8 \\
(20.6)\end{array}$ & $\begin{array}{c}3.4 \\
(3.5)\end{array}$ & $\begin{array}{c}24.0 \\
(23.0)\end{array}$ & $\begin{array}{c}23.0 \\
(22.4)\end{array}$ & $\begin{array}{c}20.4 \\
(19.0)\end{array}$ & $\begin{array}{l}6.0 \\
5.8\end{array}$ & $\mathrm{H}_{2} \mathrm{O}+\mathrm{EtOH}$ \\
\hline 5 & $\mathrm{C}_{16.5} \mathrm{H}_{29.5} \mathrm{Cl}_{5} \mathrm{~N}_{13.5} \mathrm{O}_{6.5} \mathrm{Cu}_{4}$ & 952.5 & $\begin{array}{c}20.3 \\
(20.8)\end{array}$ & $\begin{array}{c}3.0 \\
(3.1)\end{array}$ & $\begin{array}{c}26.5 \\
(26.7)\end{array}$ & $\begin{array}{c}18.6 \\
(18.6)\end{array}$ & $\begin{array}{c}19.1 \\
(19.9)\end{array}$ & $\begin{array}{c}8.5 \\
(8.2)\end{array}$ & $\mathrm{EtOH}+\mathrm{H}_{2} \mathrm{O}$ \\
\hline 6 & $\mathrm{C}_{10} \mathrm{H}_{22} \mathrm{Cl}_{3} \mathrm{~N}_{6} \mathrm{O}_{5.5} \mathrm{Cu}_{3}$ & 611.3 & $\begin{array}{c}18.6 \\
(19.6)\end{array}$ & $\begin{array}{c}3.0 \\
(3.6)\end{array}$ & $\begin{array}{c}31.9 \\
(31.2)\end{array}$ & $\begin{array}{c}15.5 \\
(17.4)\end{array}$ & $\begin{array}{c}14,2 \\
(13.8)\end{array}$ & $\begin{array}{c}12.4 \\
(12.0)\end{array}$ & $\mathrm{EtOH}+\mathrm{H}_{2} \mathrm{O}$ \\
\hline 7 & $\mathrm{C}_{16.5} \mathrm{H}_{29.5} \mathrm{Cl}_{5} \mathrm{~N}_{135} \mathrm{O}_{6.5} \mathrm{Cu}_{4}$ & 1719.2 & $\begin{array}{c}19.5 \\
(19.9)\end{array}$ & $\begin{array}{c}3.1 \\
(3.0)\end{array}$ & $\begin{array}{c}21.7 \\
(22.0)\end{array}$ & $\begin{array}{c}22.2 \\
(22.7)\end{array}$ & $\begin{array}{c}22.0 \\
(22.0)\end{array}$ & $\begin{array}{c}3.4 \\
(3.3)\end{array}$ & Propanol $+\mathrm{H}_{2} \mathrm{O}$ \\
\hline 8 & $\mathrm{C}_{16} \mathrm{H}_{31} \mathrm{Cl}_{5} \mathrm{~N}_{12} \mathrm{O}_{6} \mathrm{Cu}_{3}$ & 855.4 & $\begin{array}{c}22.6 \\
(22.5)\end{array}$ & $\begin{array}{c}3.3 \\
(3.7)\end{array}$ & $\begin{array}{c}21.9 \\
(22.3)\end{array}$ & $\begin{array}{c}21.4 \\
(20.7)\end{array}$ & $\begin{array}{c}19.1 \\
(19.7)\end{array}$ & $\begin{array}{c}10.5 \\
(10.8)\end{array}$ & $\mathrm{EtOH}$ \\
\hline 9 & $\mathrm{C}_{11} \mathrm{H}_{19} \mathrm{Cl}_{4} \mathrm{~N}_{9} \mathrm{O}_{4} \mathrm{Cu}_{3}$ & 673.8 & $\begin{array}{c}18.6 \\
(19.6)\end{array}$ & $\begin{array}{c}2.8 \\
(2.8)\end{array}$ & $\begin{array}{c}27.9 \\
(28.3)\end{array}$ & $\begin{array}{c}21.2 \\
(21.1)\end{array}$ & $\begin{array}{c}19.4 \\
(18.7)\end{array}$ & $\begin{array}{c}6.4 \\
(6.8)\end{array}$ & $\mathrm{EtOH}$ \\
\hline 10 & $\mathrm{C}_{38} \mathrm{H}_{66} \mathrm{Cl}_{10} \mathrm{~N}_{30} \mathrm{O}_{12} \mathrm{Cu}_{7}$ & 1934.5 & $\begin{array}{c}23.2 \\
(23.6)\end{array}$ & $\begin{array}{c}3.3 \\
(3.4)\end{array}$ & $\begin{array}{c}22.7 \\
(23.0)\end{array}$ & $\begin{array}{c}18.3 \\
(18.3)\end{array}$ & $\begin{array}{c}21.9 \\
(21.7)\end{array}$ & $\begin{array}{c}7.4 \\
(7.7)\end{array}$ & Butanol \\
\hline 11 & $\mathrm{C}_{28} \mathrm{H}_{48} \mathrm{Cl}_{4} \mathrm{~N}_{18} \mathrm{O}_{8} \mathrm{Cu}_{5}$ & 1224.4 & $\begin{array}{c}27.4 \\
(27.5)\end{array}$ & $\begin{array}{c}3.0 \\
(4.0)\end{array}$ & $\begin{array}{c}25.3 \\
(26.0)\end{array}$ & $\begin{array}{c}11.5 \\
(11.6)\end{array}$ & $\begin{array}{c}20.9 \\
(20.6)\end{array}$ & $\begin{array}{c}14.0 \\
(14.4)\end{array}$ & Pentanol \\
\hline 12 & $\mathrm{C}_{20.5} \mathrm{H}_{35} \mathrm{Cl}_{7} \mathrm{~N}_{18} \mathrm{O}_{6.5} \mathrm{Cu}_{4}$ & 1140.0 & $\begin{array}{c}21.1 \\
(21.6)\end{array}$ & $\begin{array}{c}3.1 \\
(3.1)\end{array}$ & $\begin{array}{c}22.7 \\
(21.8)\end{array}$ & $\begin{array}{c}22.6 \\
(21.8)\end{array}$ & $\begin{array}{c}21.7 \\
(22.1)\end{array}$ & $\begin{array}{c}3.8 \\
(3.9)\end{array}$ & Pentanol \\
\hline
\end{tabular}


Table 2. The most important IR, electronic spectral bands and the values of $U_{\text {eff. }}$

\begin{tabular}{|c|c|c|c|c|c|c|c|c|c|c|c|}
\hline Compd. & $v(\mathrm{OH})$ & $v\left(\mathrm{NH}_{2}\right)$ & $v(\mathrm{C} \equiv \mathrm{N})$ & $\begin{array}{c}v(\mathrm{C}=\mathrm{O}) \\
\text { Amide I band }\end{array}$ & $v\left(\mathrm{NH}_{2}\right)$ & $\begin{array}{l}\text { Amide II } \\
\text { band }\end{array}$ & $v(\mathrm{~N}-\mathrm{N})$ & $v(\mathrm{M}-\mathrm{O})$ & $v(\mathrm{M}-\mathrm{N})$ & $\begin{array}{c}\lambda(\mathrm{nm}) \text { in } v\left(\mathrm{~cm}^{-1}\right) \\
\text { Nujol }\end{array}$ & ' $U_{\text {eff }}(\mathrm{BM})$ \\
\hline $\mathrm{L}^{1}$ & - & 3280,3199 & 2263 & 1710,1680 & 1619 & 1530,1492 & 998 & .......... & ......... & $257.3,38,865$ & -1.95 \\
\hline 1 & 3440 & 3182,2997 & 2264 & 1660,1634 & 1586 & 1519,1435 & 975 & 440 & 350 & $800,12,500$ & 1.95 \\
\hline 2 & 3400 & 3320,3185 & 2260 & 1720,1670 & 1589 & 1401 & 940 & 400 & 335 & $740,13,514$ & 0.91 \\
\hline 3 & 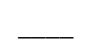 & 3445,2993 & 2264 & 1760,1640 & 1585 & 1440,1360 & 980 & 440 & 388 & $800,12,500$ & 1.24 \\
\hline 4 & 3400 & 3180,3100 & 2264 & 1710,1640 & 1582 & 1440,1400 & 975 & 439 & 385 & $780,12,821$ & 1.02 \\
\hline 5 & & 3180,3210 & _ & 1700,1650 & 1585 & 1445,1395 & 976 & 425 & 390 & $780,12,821$ & 1.14 \\
\hline 6 & 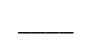 & 3415,3346 & 2270 & 1740,1600 & 1540 & 1406,1300 & 940 & 400 & 360 & $830,12,408$ & 0.78 \\
\hline 7 & 3480 & $3220,3170,2980$ & 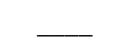 & 1636 & 1618 & 1575,1540 & 955 & 400 & 345 & $760,13,158$ & 0.75 \\
\hline 8 & 3350 & $2968,2930,2800$ & 2260 & 1720 & 1590 & 1529,1402 & 940 & 440 & 399 & $750,13,333$ & 0.85 \\
\hline 9 & 3440 & $3280,3231,3180$ & 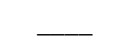 & 1638 & 1620 & 1572,1440 & 940 & 433 & 400 & $760,13,158$ & $0.86,0.89$ \\
\hline 10 & 3426 & 3200,2987 & 2263 & 1700,1660 & 1590 & 1531,1430 & 980 & 440 & 400 & $780,12,821$ & 0.78 \\
\hline 11 & 3420 & 3260,3200 & 2260 & 1700 & 1621 & 1540,1416 & 953 & 450 & 389 & $740,13,514$ & 0.84 \\
\hline 12 & 3426 & 3200 & 2263,2170 & 1700,1660 & 1590 & 1537,1430 & 940 & 440 & 400 & $730,13,699$ & 0.88 \\
\hline
\end{tabular}

Complex (5) $\left(\mathrm{C}_{16.5} \mathrm{H}_{29.5} \mathrm{Cl}_{5} \mathrm{~N}_{13.5} \mathrm{O}_{6.5} \mathrm{Cu}_{4}\right)$; yield: 69\%; color: brown powder; $\mathrm{MP}$ > $270^{\circ} \mathrm{C}$; M.Wt: $952.5 ; \mu_{\text {eff }}(1.14 \mathrm{BM})$; conductivity (DMSO): $13 \Omega^{-1} \cdot \mathrm{cm}^{2} \cdot \mathrm{mol}^{-1}$.

Complex (6) $\left(\mathrm{C}_{10} \mathrm{H}_{22} \mathrm{Cl}_{3} \mathrm{~N}_{6} \mathrm{O}_{5.5} \mathrm{Cu}_{3}\right)$; yield: 69\%; color: brown powder; $\mathrm{MP}>$ $270^{\circ} \mathrm{C}$; M.Wt: $611.3 ; \mu_{\text {eff }}(0.78 \mathrm{BM})$; conductivity (DMSO): $8 \Omega^{-1} \cdot \mathrm{cm}^{2} \cdot \mathrm{mol}^{-1}$.

Complex (7) $\left(\mathrm{C}_{16.5} \mathrm{H}_{29.5} \mathrm{Cl}_{5} \mathrm{~N}_{13.5} \mathrm{O}_{6.5} \mathrm{Cu}_{4}\right)$; yield: 77\%; color: yellowish-green powder; MP $155^{\circ}$ C; M.Wt: $1719.2 ; \mu_{\text {eff }}(0.75 \mathrm{BM})$; conductivity (DMSO): $7 \Omega^{-1} \cdot \mathrm{cm}^{2} \cdot \mathrm{mol}^{-1}$.

Complex (8) $\left(\mathrm{C}_{16} \mathrm{H}_{31} \mathrm{Cl}_{5} \mathrm{~N}_{12} \mathrm{O}_{6} \mathrm{Cu}_{3}\right)$; yield: 77\%; color: dirty-green powder; $\mathrm{MP}>$ $270^{\circ} \mathrm{C}$; M.Wt: $855.4 ; \mu_{\text {eff }}(0.85 \mathrm{BM})$; conductivity (DMSO): $6 \Omega^{-1} \cdot \mathrm{cm}^{2} \cdot \mathrm{mol}^{-1}$.

Complex (9) $\left(\mathrm{C}_{11} \mathrm{H}_{19} \mathrm{Cl}_{4} \mathrm{~N}_{9} \mathrm{O}_{4} \mathrm{Cu}_{3}\right)$; yield: $90 \%$; color: military-green powder; MP > 270 ${ }^{\circ}$ C; M.Wt: $673.8 ; \mu_{\text {eff }}(0.85 \mathrm{BM})$; conductivity (DMSO): $4 \Omega^{-1} \cdot \mathrm{cm}^{2} \cdot \mathrm{mol}^{-1}$.

Complex (10) $\left(\mathrm{C}_{38} \mathrm{H}_{66} \mathrm{Cl}_{10} \mathrm{~N}_{30} \mathrm{O}_{12} \mathrm{Cu}_{7}\right)$ : yield: $85 \%$; color: kaki-green powder; MP > 270 ${ }^{\circ}$; M.Wt: $1934.5 ; \mu_{\text {eff }}(0.75 \mathrm{BM})$; conductivity (DMSO): $9 \Omega^{-1} \cdot \mathrm{cm}^{2} \cdot \mathrm{mol}^{-1}$.

Complex (11) $\left(\mathrm{C}_{28} \mathrm{H}_{48} \mathrm{Cl}_{4} \mathrm{~N}_{18} \mathrm{O}_{8} \mathrm{Cu}_{5}\right)$; yield: 79\%; color: brownish-green powder; MP: $200^{\circ}$ C; M.Wt: $1224.4 ; \mu_{\text {eff }}\left(0.84 \mathrm{BM}\right.$ ); conductivity (DMSO): $10 \Omega^{-1} \cdot \mathrm{cm}^{2} \cdot \mathrm{mol}^{-1}$.

Complex (12) $\left(\mathrm{C}_{20.5} \mathrm{H}_{35} \mathrm{Cl}_{7} \mathrm{~N}_{18} \mathrm{O}_{6.5} \mathrm{Cu}_{4}\right)$; yield: $85 \%$; color: grayish-green powder; MP: $103^{\circ} \mathrm{C}$; M.Wt: $1140.0 ; \mu_{\text {eff }}(0.85 \mathrm{BM})$; conductivity (DMSO): $10 \Omega^{-1} \cdot \mathrm{cm}^{2} \cdot \mathrm{mol}^{-1}$.

\section{Results and Discussion}

The data of some physical properties and elemental analysis of the isolated $\mathrm{Cu}^{2+}$ complexes are summarized in Table 1. The structures of the compounds are established by elemental analyses, spectral, magnetic studies and confirmed by weight loss determination. The values of molar conductivity of all complexes lie in the $4-13 \mathrm{ohm}^{-1} \cdot \mathrm{cm}^{2} \cdot \mathrm{mol}^{-1}$ range indicating the non-electrolytic nature of the $\mathrm{Cu}^{2+}$ complexes [21]. Also, it suggests the polymeric nature as well as the strong covalent bonding between the ligand and the copper(II) ion. Unfortunately, the 
isolation of single crystal for any one of the isolated solid complexes to confirm the exact coordination sites and the geometry around the $\mathrm{Cu}^{2+}$ ions is very difficult due to the polymeric nature of these complexes.

\subsection{IR, ${ }^{1} \mathrm{H}-\mathrm{NMR}$, Raman, Electronic and Mass Spectra of L (CAH)}

The IR spectra of CAH (L) in $\mathrm{KBr}$ and/or Nujol mull are cognate and show three bands at 3280sh, 3199s and 3056s cm $\mathrm{cm}^{-1}$ assigned to $v_{\mathrm{a}}\left(\mathrm{NH}_{2}\right), v_{\mathrm{s}}\left(\mathrm{NH}_{2}\right)$ and $v_{\mathrm{a}}\left(\mathrm{NH}_{2}\right)$ vibrations, respectively. Also, the bands located at 2263s, 1710sh and $1680 \mathrm{sh} \mathrm{cm}^{-1}$ are assigned to $v(\mathrm{C} \equiv \mathrm{N}) \mathrm{s}, v(\mathrm{C}=\mathrm{O})$ sh (free) and $v(\mathrm{C}=\mathrm{O})$ s (hydrogen-bonded) vibrations, respectively. Moreover, the two bands at $1530 \mathrm{~m}$ and $1492 \mathrm{~s}$ are attributed to amide II vibrations. The observation of the carbonyl band as a shoulder together with the existence of the $\mathrm{NH}_{2}$ at lower wavelength suggests that the carbonyl group is partially hydrogen-bonded to the amino group as shown in Figure 1. Also, the ${ }^{1} \mathrm{H}-\mathrm{NMR}$ spectrum of $\mathrm{L}$ in $\mathrm{d}_{6}$-DMSO shows three signals at 10.06, 9.53 and $9.1 \mathrm{ppm}$ assigned to $\mathrm{NH}_{2}$ and $\mathrm{NH}$ groups which obscured on adding $\mathrm{D}_{2} \mathrm{O}$. Both the methyl and ethyl proton signals are observed as triplet signals in the ranges $1.76-1.96$ and $3.66-3.76 \mathrm{ppm}$, respectively. The calculated value of the mass spectrum of $\mathrm{L}$ equals 141 which is quite agrees with the experimental value of $M+1$ (142). The electronic spectrum of $L$ in DMSO shows two bands at $220 \mathrm{~nm}\left(45,455 \mathrm{~cm}^{-1}\right)$ and $262 \mathrm{~nm}\left(38,170 \mathrm{~cm}^{-1}\right)$ attributed to $\pi \rightarrow \pi^{*}$ and $\pi \rightarrow \pi^{*}$ transitions of the $\mathrm{C}=\mathrm{O}$ and $\mathrm{C} \equiv \mathrm{N}$ groups, respectively. The Raman spectrum of $\mathrm{CAH}$ shows active bands at $3341 \mathrm{~m}, 2926 \mathrm{~m}, 2260 \mathrm{~s} 1670 \mathrm{w}$ and $1010 \mathrm{~cm}^{-1}$ assigned to $v\left(\mathrm{NH}_{2}\right), v(\mathrm{CH}), v(\mathrm{C} \equiv \mathrm{N})$ and $v(\mathrm{~N}-\mathrm{N})$ vibrations, respectively. These foundations are taken as strong evidences for our assumptions and the existence of the ligand (CAH) as shown in Figure 1.

A comparison of the IR spectra of $\mathrm{CAH}$ and its $\mathrm{Cu}^{2+}$ complexes (Table 2) shows that the ligand behaves in a neutral bidentate fashion via the $(\mathrm{C}=\mathrm{O})$ and $\mathrm{NH}_{2}$ groups.

The mode of chelation is confirmed by the following remarks:

1) The measurably shifts of both the $(\mathrm{C}=\mathrm{O})$ and $\left(\mathrm{NH}_{2}\right)$ groups to lower wavenumbers in all complexes indicating that these groups are participating in coordination of the $\mathrm{Cu}^{2+}$ ion.

2) The vibrations of the amide II bands are also shifted to lower wavenumbers suggesting the participation of both groups in coordination.

3) New bands are observed in the range $400-440$ and $350-400 \mathrm{~cm}^{-1}$ are assigned to $(\mathrm{M}-\mathrm{O})$ and $(\mathrm{M}-\mathrm{N})$, respectively [13].

4) The spectra of the complexes show broad medium band in the region 3440 - $3426 \mathrm{~cm}^{-1}$, attributable to the existence of solvent inside and/or outside the coordination sphere [14].

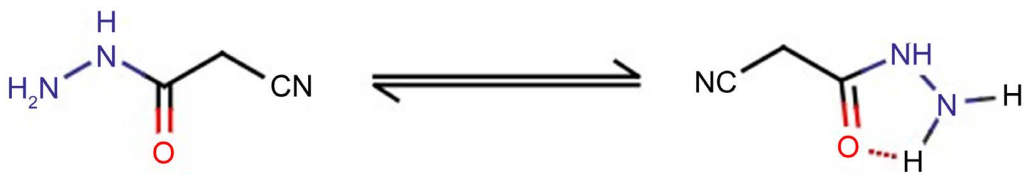

Figure 1. Hydrogen bond exists in $\mathrm{CAH}\left(\mathbf{L}^{1}\right)$. 
5) The observation of two bands at 1710s and 1680sh together with the presence of weak broad bands in the $2800-2920 \mathrm{~cm}^{-1}$ suggests the existence of strong hydrogen bonding.

All these foundations suggest that the ligand is existed as a mixture of the keto (A) and enol (B) forms as shown in Figure 1.

The obscure and/or the weakness of the cyano group $(C \equiv N)$ in some $\mathrm{Cu}^{2+}$ complexes is taken as strong evidence for the promotion of the solvent as shown in Scheme 1. The mechanism of promotion was proposed and confirmed in our previous works [18] [19].

\subsection{Molecular Modeling}

\section{Global Reactivity Descriptors}

Quantum chemical calculations are concerned with the determination of energies of both HOMO ( $\pi$-donor) and LUMO ( $\pi$-acceptor) parameters. HOMO orbital acts as an electron donor while LUMO orbital acts as an electron acceptor. These molecular orbitals are also called the frontier molecular orbitals (FMOs).

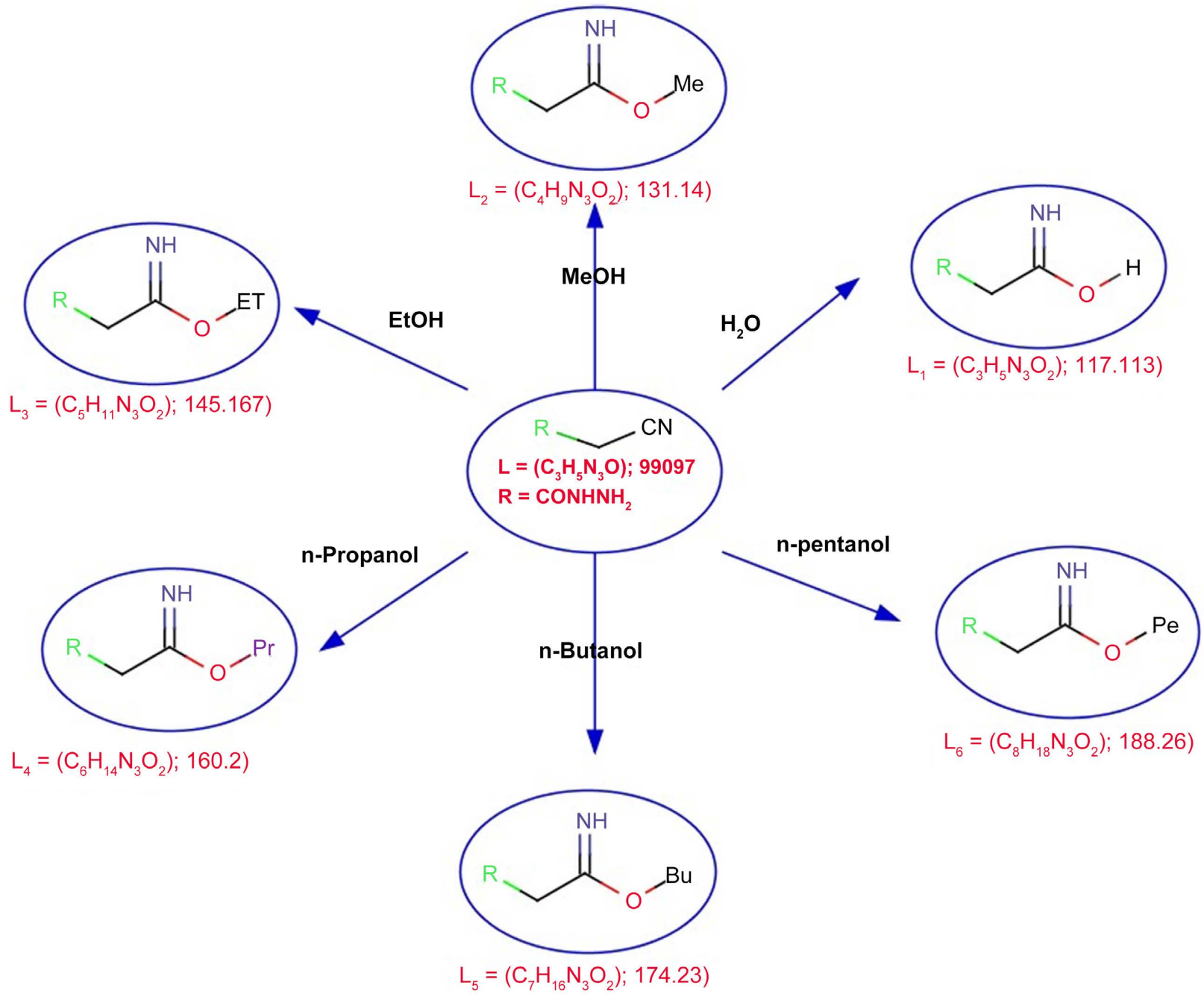

Scheme 1. Promotion of solvents to the cyano group. 
1) The negative values of both $E_{\mathrm{Hомо}}$ and $E_{\mathrm{LU}}$ and their neighboring orbitals (Table 3) indicate that the molecules are stable [22].

2) The FMOs theory predicts the essential sites participate in coordination (electrophilic attack). An initial assumption proposes that the reaction occurred with maximum overlap between the HOMO on one molecule and the LUMO on the other. The overlap between HOMO and the LUMO is essential factor in any reactions. The goal obtained from the calculations is to get the largest values of molecular orbital coefficients. Accordingly the orbitals of the ligands under investigation have the largest value of molecular orbital.

3) Gutmann's variation rules indicate that the strength of bonds increase as the adjacent bonds become weaker as found by Linert et al. [23].

4) The energy gap ( $\left.E_{\text {Номо }}-E_{\mathrm{LUMO}}\right)$ expresses the stability index which helps to characterize the chemical reactivity and kinetic stability of the molecule [24]. The gap $\left(E_{\mathrm{HOMO}}-E_{\mathrm{LUmO}}\right)$ is patented to develop a theoretical model to explain the structure and verify the barriers in different systems, which affect the biological activity of the molecule. Small gap within the molecule means that the molecule is polarized and acts as soft molecule. It is well known that the soft molecules are more reactive than hard ones since they easily donate electrons to an acceptor. The energy gap is small in the compound indicate that the charge-transfer easily occurs in it influencing the biological activity of the molecule. Energy gap with low values is also attributed to the groups that enter into conjugation [24].

5) Low energy values of HOMO indicate that the donating electron ability of the molecules is the weaker. Contrarily, the higher HOMO energy suggests that the molecule is a good electron donor. LUMO energy presents the ability of a molecule receiving electron [25]. The results are depicted in Figures 2-7.

DFT concept illustrates neatly the chemical reactivity and the site selectivity of the molecular systems. Both the energies of $\left(E_{\mathrm{HOMO}}+E_{\mathrm{LUMO}}\right)$ and band gap $\left(E_{\text {Номо }}-\right.$ $\left.E_{\text {LUмо }}\right)$ illustrate preemptory the charge-transfer interplay within the molecule, electronegativity $(\chi)$, chemical potential $(\mu)$, global hardness $(\eta)$, global softness $(S)$ and global electrophilicity index $(\omega)$ [26] [27] [28] are listed in Table 4.

$$
\chi=-1 / 2\left(E_{\text {LUMо }}+E_{\text {номо }}\right)
$$

Table 3. Some of energetic properties of the ligands and calculated by $\mathrm{DMOL}^{3}$ using DFT-method.

\begin{tabular}{cccccccc}
\hline No. & Compound & $\begin{array}{c}\mathrm{HOMO} \\
(\mathrm{eV})\end{array}$ & $\begin{array}{c}\text { LUMO } \\
(\mathrm{eV})\end{array}$ & $\begin{array}{c}E_{\mathrm{HOMO}}-E_{\text {LOMO }} \\
(\mathrm{eV})\end{array}$ & $\begin{array}{c}\text { Binding energy } \\
(\mathrm{Kcal} / \mathrm{mol})\end{array}$ & $\begin{array}{c}\text { Total energy } \\
(\mathrm{Kcal} / \mathrm{mol})\end{array}$ & $\begin{array}{c}\text { Kinetic energy } \\
(\mathrm{Kcal} / \mathrm{mol})\end{array}$ \\
\hline $\mathbf{1}$ & $\mathrm{L} ; \mathrm{CAH}\left(\mathrm{C}_{3} \mathrm{H}_{5} \mathrm{~N}_{3} \mathrm{O}\right)$ & -5.575 & -0.449 & -5.126 & -1233.73 & $-2.24 \times 10^{5}$ & -2106.03 \\
$\mathbf{2}$ & $\mathrm{L}^{1} ;\left(\mathrm{C}_{3} \mathrm{H}_{7} \mathrm{~N}_{3} \mathrm{O}_{2}\right)$ & -5.538 & -0.321 & -5.217 & -1500.15 & $-2.72 \times 10^{5}$ & -2267.83 \\
$\mathbf{3}$ & $\mathrm{L}^{2} ;\left(\mathrm{C}_{4} \mathrm{H}_{9} \mathrm{~N}_{3} \mathrm{O}_{2}\right)$ & -4.802 & 0.405 & -4.397 & -1748.98 & $2.96 \times 10^{5}$ & -1910.25 \\
$\mathbf{4}$ & $\mathrm{L}^{3} ;\left(\mathrm{C}_{5} \mathrm{H}_{11} \mathrm{~N}_{3} \mathrm{O}_{2}\right)$ & -5.36 & -0.242 & -5.118 & -2063.23 & $-3.21 \times 10^{5}$ & -3174.85 \\
$\mathbf{5}$ & $\mathrm{L}^{4} ;\left(\mathrm{C}_{6} \mathrm{H}_{14} \mathrm{~N}_{3} \mathrm{O}_{2}\right)$ & -5.597 & -0.243 & -5.354 & -2358.60 & $-3.46 \times 10^{5}$ & -3538.18 \\
$\mathbf{6}$ & $\mathrm{L}^{5} ;\left(\mathrm{C}_{7} \mathrm{H}_{16} \mathrm{~N}_{3} \mathrm{O}_{2}\right)$ & -5.630 & -0.293 & -5.337 & -2655.31 & $-3.70 \times 10^{5}$ & -3879.51 \\
7 & $\mathrm{~L}^{6} ;\left(\mathrm{C}_{8} \mathrm{H}_{18} \mathrm{~N}_{3} \mathrm{O}_{2}\right)$ & -5.832 & -0.529 & -5.303 & -2949.04 & $-3.95 \times 10^{5}$ & -4468.66 \\
\hline
\end{tabular}




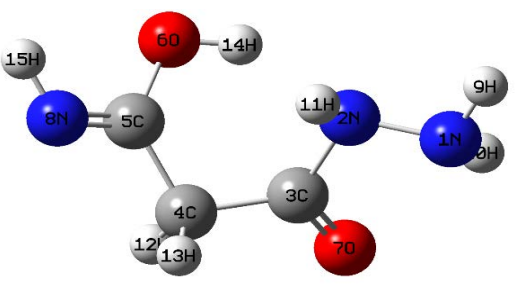

(a)

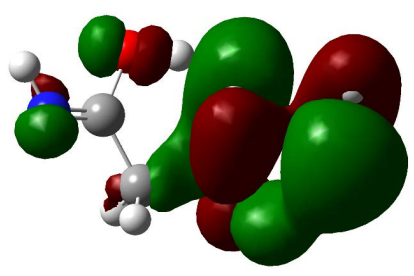

(c)

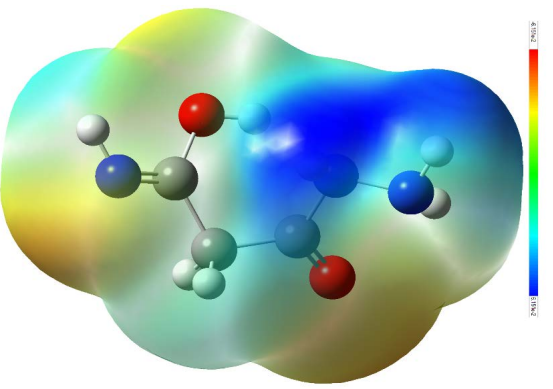

(b)

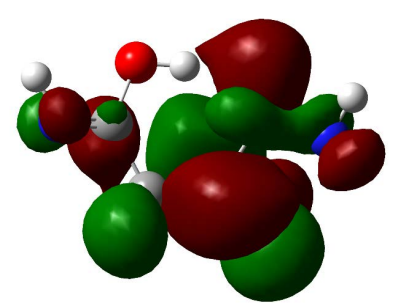

(d)

Figure 2. (a, b, c, d) Molecular modeling of (a) $\mathrm{L}^{1}$, (b) electron density, (c) HOMO, and (d) LUMO.

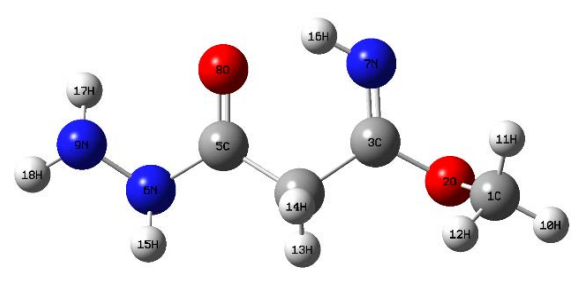

(a)

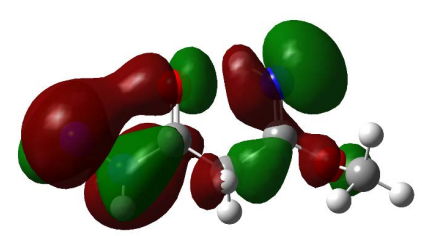

(c)

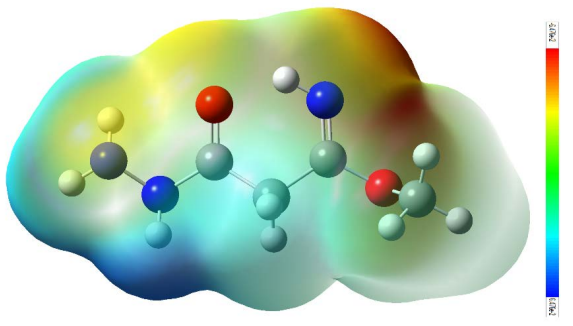

(b)

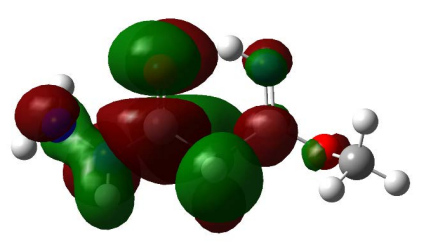

(d)

Figure 3. (a, b, c, d) Molecular modeling of (a) $\mathrm{L}^{2}$, (b) electron density, (c) HOMO, and (d) LUMO.

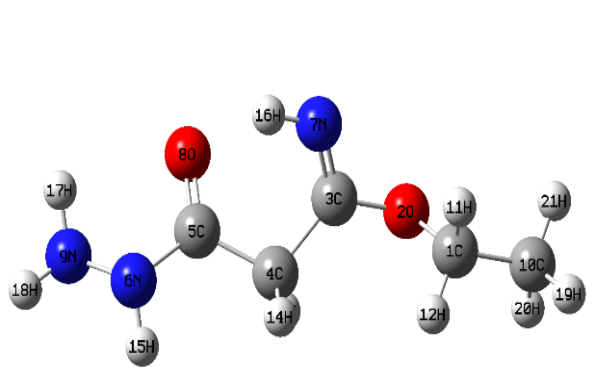

(a)

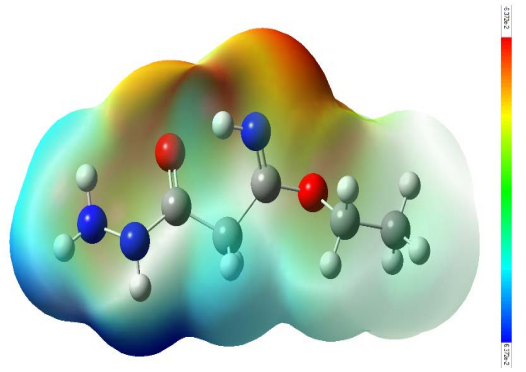

(b) 


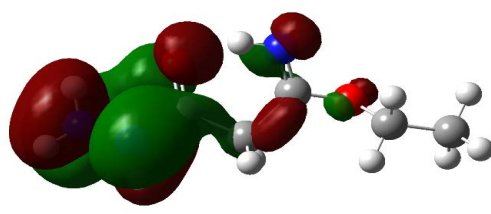

(c)

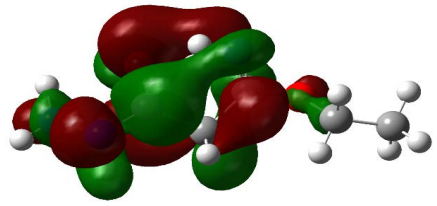

(d)

Figure 4. (a, b, c, d) Molecular modeling of (a) $\mathrm{L}^{3}$, (b) electron density, (c) HOMO, and (d) LUMO.

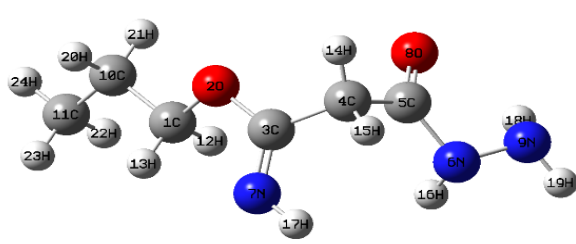

(a)

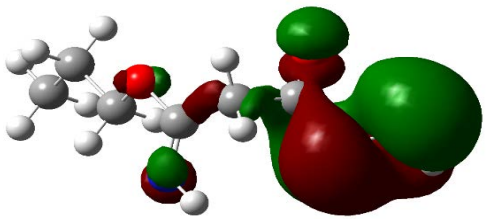

(c)

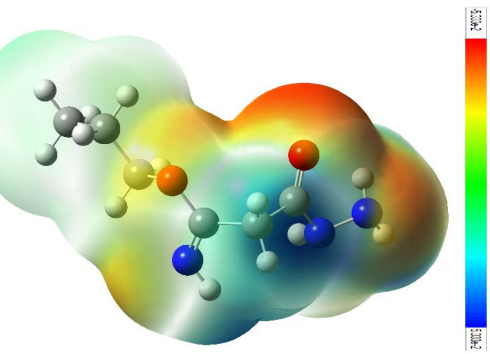

(b)

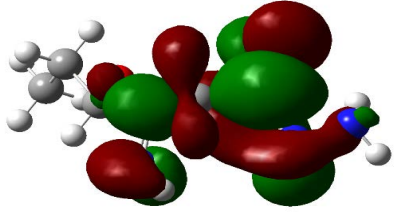

(d)

Figure 5. (a, b, c, d) Molecular modeling of (a) $\mathrm{L}^{4}$, (b) electron density, (c) HOMO, and (d) LUMO.

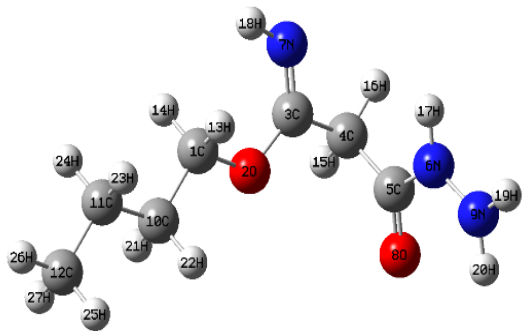

(a)

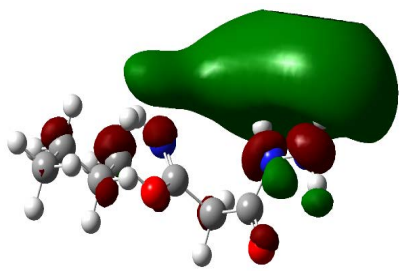

(c)

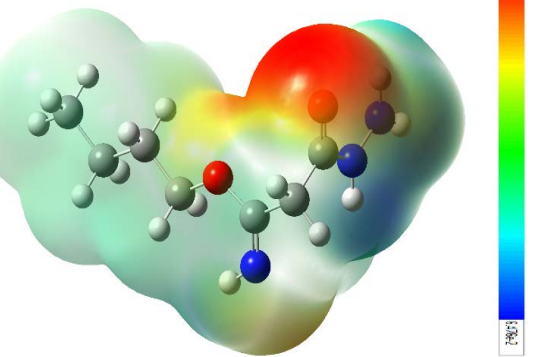

(b)

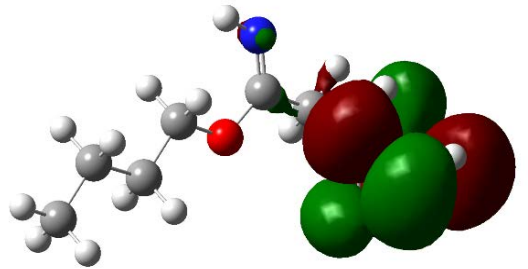

(d)

Figure 6. (a, b, c, d) Molecular modeling of (a) $\mathrm{L}^{5}$, (b) electron density, (c) HOMO, and (d) LUMO. 


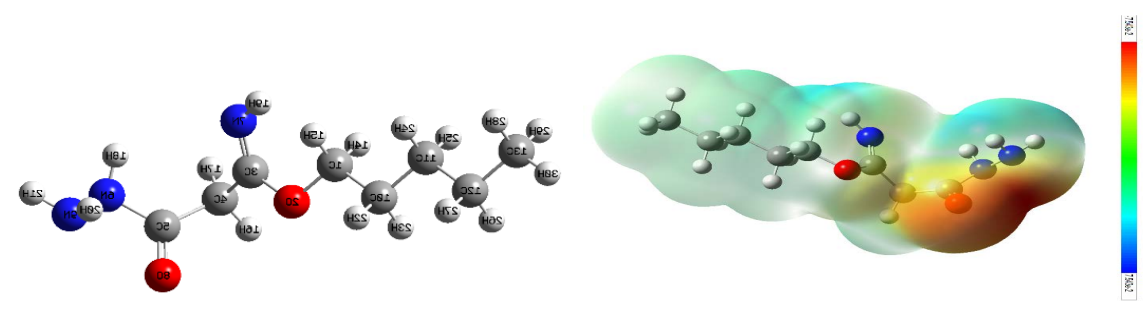

(a)

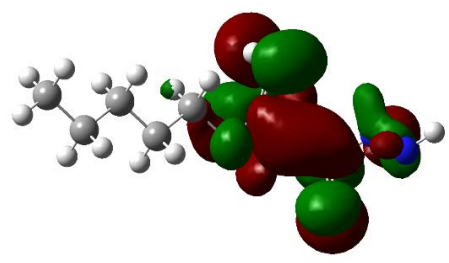

(c) (b)

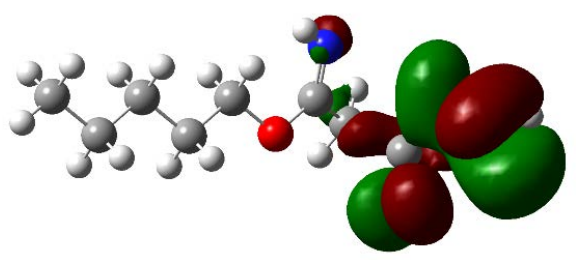

(d)

Figure 7. (a, b, c, d) Molecular modeling of (a) $\mathrm{L}^{6}$, (b) electron density, (c) HOMO, and (d) LUMO.

Table 4. Calculated $E_{\text {Hомо, }} E_{\mathrm{Lumo}}$, energy band gap $\left(E_{\mathrm{H}}-E_{\mathrm{L}}\right)$, chemical potential $(\mu)$, electro-negativity $(\chi)$, global hardness $(\eta)$, global softness $(S)$ and global electrophilicity index $(\omega)$ for ligands.

\begin{tabular}{|c|c|c|c|c|c|c|c|c|c|}
\hline Compound & $\begin{array}{l}E_{\mathrm{H}} \\
\mathrm{eV}\end{array}$ & $\begin{array}{c}E_{\mathrm{L}} \\
\mathrm{eV}\end{array}$ & $\begin{array}{c}\left(E_{\mathrm{H}}-E_{\mathrm{L}}\right) \\
\mathrm{eV}\end{array}$ & $\begin{array}{c}\chi \\
\mathrm{eV}\end{array}$ & $\begin{array}{c}\mu \\
\mathrm{eV}\end{array}$ & $\begin{array}{c}\eta \\
\mathrm{eV}\end{array}$ & $\begin{array}{c}S \\
\mathrm{eV}^{-1}\end{array}$ & $\begin{array}{c}\Omega \\
\mathrm{eV}\end{array}$ & $\begin{array}{c}\Sigma \\
\mathrm{eV}\end{array}$ \\
\hline $\mathrm{L} ; \mathrm{CAH}\left(\mathrm{C}_{3} \mathrm{H}_{5} \mathrm{~N}_{3} \mathrm{O}\right)$ & -5.575 & -0.449 & -5.126 & 3.01 & -3.01 & 2.56 & 1.28 & 1.76 & 0.39 \\
\hline $\mathrm{L}^{1} ;\left(\mathrm{C}_{3} \mathrm{H}_{7} \mathrm{~N}_{3} \mathrm{O}_{2}\right)$ & -5.538 & -0.321 & -5.217 & 2.93 & -2.93 & 2.61 & 1.31 & 1.64 & 0.38 \\
\hline $\mathrm{L}^{2} ;\left(\mathrm{C}_{4} \mathrm{H}_{9} \mathrm{~N}_{3} \mathrm{O}_{2}\right)$ & -4.802 & 0.405 & -4.397 & 2.6 & -2.6 & 2.2 & 1.1 & 1.53 & 0.45 \\
\hline $\mathrm{L}^{3} ;\left(\mathrm{C}_{5} \mathrm{H}_{11} \mathrm{~N}_{3} \mathrm{O}_{2}\right)$ & -5.36 & -0.242 & -5.118 & 2.8 & -2.8 & 2.56 & 1.28 & 1.53 & 0.39 \\
\hline $\mathrm{L}^{4} ;\left(\mathrm{C}_{6} \mathrm{H}_{14} \mathrm{~N}_{3} \mathrm{O}_{2}\right)$ & -5.597 & -0.243 & -5.354 & 2.92 & -2.92 & 2.67 & 1.34 & 1.59 & 0.37 \\
\hline $\mathrm{L}^{5} ;\left(\mathrm{C}_{7} \mathrm{H}_{16} \mathrm{~N}_{3} \mathrm{O}_{2}\right)$ & -5.630 & -0.293 & -5.337 & 2.96 & -2.96 & 2.67 & 1.34 & 1.64 & 0.37 \\
\hline $\mathrm{L}^{6} ;\left(\mathrm{C}_{8} \mathrm{H}_{18} \mathrm{~N}_{3} \mathrm{O}_{2}\right)$ & -5.832 & -0.529 & -5.303 & 3.18 & -3.18 & 2.65 & 1.32 & 1.9 & 0.38 \\
\hline
\end{tabular}

$\mathrm{H}=\mathrm{HOMO}, \mathrm{L}=\mathrm{LUMO}$.

$$
\begin{gathered}
\mu=-\chi=1 / 2\left(E_{\mathrm{LUMO}}+E_{\mathrm{HOMO}}\right) \\
\eta=1 / 2\left(E_{\mathrm{LUMO}}-E_{\mathrm{HOMO}}\right) \\
S=1 / 2 \eta \\
\omega=\mu^{2} / 2 \eta
\end{gathered}
$$

The inverse value of the global hardness is designed as the softness $(\sigma)$ as follow:

$$
\sigma=1 / \eta
$$

The electrophilicity index $(\omega)$ is considered as important quantum chemical descriptors. Also, this value used to estimate the stabilization energy when the system acquires an additional electronic charge from the environment. The molecular stability and reactivity of the compounds depends mainly on the values of 
$\eta$ and $\sigma$. The ligand acts as a Lewis base while the metal ion acts as a Lewis acid during complex formation.

The three-dimensional plots of frontier orbital energies using the DFT method for $\mathrm{L}^{2}-\mathrm{L}^{7}$ are shown in Figures S1-S6.

\subsection{EPR Spectral Studies of the Isolated CuII Complexes}

The results of the EPR spectra of the polymeric $\mathrm{Cu}^{2+}$ complexes in DMSO at low temperature $\left(127^{\circ} \mathrm{C}-160^{\circ} \mathrm{C}\right)$ are depicted in Table 5. The trend $g_{\|}>g_{\perp}>g_{e}$ (2.0023) observed for the $\mathrm{Cu}^{2+}$ complexes suggests that the unpaired electron is localized in the $d_{x 2-y 2}\left({ }^{2} B_{1 g}\right)$ orbital [29] [30]. It is well known that the axial symmetry parameter $(G)$ is defined as:

$$
G=\left(g_{\|}-2.0023\right) /\left(g_{\perp}-2.0023\right)
$$

If $G>4$ the exchange interaction is negligible between $\mathrm{Cu}(\mathrm{II})$ ions, whereas $G$ $<4$ means a significant $\mathrm{Cu}-\mathrm{Cu}$ interaction and tone straightly with measured magnetic moment [31]. The $G$ values for all complexes are larger than 4 (4.0 6.0) suggesting the absence of any copper-copper interaction. Orbital reduction factors $\left(K_{\|}\right.$and $\left.K_{\perp}\right)$ which are a measure of covalence were determined using the following two expressions:

$$
\begin{aligned}
& { }^{2} K_{\|}=\frac{\left(g_{\|}-2.0023\right)}{8 \lambda o} \times \Delta E \\
& { }^{2} K_{\perp}=\frac{\left(g_{\perp}-2.0023\right)}{2 \lambda o} \times \Delta E
\end{aligned}
$$

The value of $\lambda o$ (spin-orbital coupling constant) for $d^{A}$-system equals -828

\begin{tabular}{|c|c|c|c|c|c|c|c|c|c|c|c|c|c|}
\hline Complex & $\begin{array}{c}\text { Temp. } \\
(K)\end{array}$ & $g_{\perp}$ & $g_{\|}$ & $g_{a v}$ & $G$ & $\begin{array}{c}A_{\|} \times 10^{-4} \\
\mathrm{~cm}^{-1}\end{array}$ & $K_{\perp}$ & $K_{\|}$ & $H$ & $g_{\|} / A_{\|}$ & $a^{2}$ & $B^{2}$ & $\gamma^{2}$ \\
\hline $\mathrm{C}_{11} \mathrm{H}_{23} \mathrm{Cl}_{2} \mathrm{~N}_{9} \mathrm{O}_{6} \mathrm{Cu}_{3}$ & 149 & 2.07 & 2.33 & 2.16 & 4.71 & 195 & 0.59 & 0.81 & 2303 & 100 & 0.94 & 0.86 & 0.63 \\
\hline $\mathrm{C}_{36} \mathrm{H}_{71} \mathrm{Cl}_{14} \mathrm{~N}_{27} \mathrm{O}_{18} \mathrm{Cu}_{12}$ & 132 & 2.07 & 2.32 & 2.15 & 4.57 & 200 & 0.55 & 0.65 & 3160 & 116 & 0.94 & 0.69 & 0.59 \\
\hline $\mathrm{C}_{31} \mathrm{H}_{75} \mathrm{Cl}_{7} \mathrm{~N}_{24} \mathrm{O}_{23} \mathrm{Cu}_{8}$ & 127 & 2.08 & 2.44 & 2.20 & 5.50 & 190 & 0.59 & 0.83 & 3200 & 136 & 0.90 & 0.92 & 0.66 \\
\hline $\mathrm{C}_{19} \mathrm{H}_{38} \mathrm{Cl}_{7} \mathrm{~N}_{15} \mathrm{O}_{8} \mathrm{Cu}_{4}$ & 160 & 2.06 & 2.29 & 2.14 & 4.83 & 190 & 0.45 & 0.56 & 3245 & 121 & 0.88 & 0.64 & 0.51 \\
\hline $\mathrm{C}_{16.5} \mathrm{H}_{29.5} \mathrm{Cl}_{5} \mathrm{~N}_{13.5} \mathrm{O}_{6.5} \mathrm{Cu}_{4}(5)$ & 155 & 2.07 & 2.33 & 2.16 & 4.71 & 185 & 0.52 & 0.64 & 3190 & 126 & 0.91 & 0.70 & 0.57 \\
\hline $\mathrm{C}_{10} \mathrm{H}_{22} \mathrm{Cl}_{3} \mathrm{~N}_{6} \mathrm{O}_{5.5} \mathrm{Cu}_{3}$ & 155 & 2.08 & 2.44 & 2.20 & 5.50 & 170 & 0.57 & 0.63 & 3150 & 144 & 0.98 & 0.64 & 0.58 \\
\hline $\mathrm{C}_{16.5} \mathrm{H}_{29.5} \mathrm{Cl}_{5} \mathrm{~N}_{135} \mathrm{O}_{6.5} \mathrm{Cu}_{4}(7)$ & 135 & 2.06 & 2.36 & 2.16 & 6.00 & 180 & 0.46 & 0.67 & 3106 & 131 & 0.92 & 0.73 & 0.50 \\
\hline $\mathrm{C}_{16} \mathrm{H}_{31} \mathrm{Cl}_{5} \mathrm{~N}_{12} \mathrm{O}_{6} \mathrm{Cu}_{3}$ & 127 & 2.07 & 2.31 & 2.15 & 4.43 & 195 & 0.55 & 0.61 & 3160 & 119 & 0.92 & 0.66 & 0.60 \\
\hline $\mathrm{C}_{11} \mathrm{H}_{19} \mathrm{Cl}_{4} \mathrm{~N}_{9} \mathrm{O}_{4} \mathrm{Cu}_{3}$ & 127 & 2.07 & 2.31 & 2.15 & 4.43 & 160 & 0.54 & 0.61 & 3240 & 144 & 0.82 & 0.74 & 0.66 \\
\hline $\mathrm{C}_{38} \mathrm{H}_{66} \mathrm{Cl}_{10} \mathrm{~N}_{30} \mathrm{O}_{12} \mathrm{Cu}_{7}$ & 139 & 2.11 & 2.43 & 2.22 & 4.00 & 170 & 0.83 & 0.83 & 3210 & 143 & 0.99 & 0.78 & 0.84 \\
\hline $\mathrm{C}_{28} \mathrm{H}_{48} \mathrm{Cl}_{4} \mathrm{~N}_{18} \mathrm{O}_{8} \mathrm{Cu}_{5}$ & 137 & 2.06 & 2.30 & 2.14 & 5.00 & 180 & 0.47 & 0.61 & 3175 & 128 & 0.87 & 0.70 & 0.54 \\
\hline $\mathrm{C}_{20.5} \mathrm{H}_{35} \mathrm{Cl}_{7} \mathrm{~N}_{18} \mathrm{O}_{6.5} \mathrm{Cu}_{4}(12)$ & 140 & 2.07 & 2.39 & 2.18 & 5.57 & 190 & 0.56 & 0.80 & 3106 & 121 & 0.89 & 0.90 & 0.63 \\
\hline
\end{tabular}
$\mathrm{cm}^{-1}$. Hathaway [31] pointed out that that in case of pure $\sigma$-bonding, $K_{\|}=K_{\perp}=$

Table 5. EPR X-band data of the $\mathrm{Cu}^{\mathrm{II}}$ complexes in DMSO at low temperature. 
0.77 and for in-plane $\pi$-bonding $K_{\|}<K_{\perp}$, while for out-of-plane $\pi$-bonding $K_{\perp}<$ $K_{\|}$the following simplified expressions were used to calculate $K_{\|}$and $K_{\perp}$. In all cases of $\mathrm{Cu}$ (II) complexes under investigation the observed $K_{\|}>K_{\perp}$ indicating that the presence of out-of-plane $\pi$-bonding as depicted in Table 5 . The value of $K_{\|}=K_{\perp}=0.83$ in case of the $\mathrm{Cu}^{2+}$ complex (10) suggesting the existence of pure $\sigma$-bonding. For all the complexes the evaluated values of $\alpha^{2}, \beta^{2}$ and $\gamma^{2}$ are consistent with both in plane $\sigma$-bonding and in plane $\pi$-bonding as shown in Table 5. Moreover, all the above values $\left(\alpha^{2}, \beta^{2}\right.$ and $\left.\gamma^{2}\right)$ are less than 1 suggesting $100 \%$ ionic nature of the bonds [32]. The bonding parameters for the $\mathrm{Cu}(\mathrm{II})$ complexes are found to be $\alpha^{2}$ in the $0.82-0.99, \beta^{2}$ in the $0.64-0.92$ and $\gamma^{2}$ in the $0.5-0.84$ ranges. The extent of departing of these parameters from unity measures the range of delocalization of metal electrons due to M-L bonding and hence $\alpha^{2}$ measures $\sigma$-bonding within the complexes [33], $\beta^{2}$ measures out of $(x y)$ plane $\pi$-bonding while $\gamma^{2}$ shows in plane $\pi$-bonding contribution. No doubt that the deviation from unity in $\beta^{2}$ and $\gamma^{2}$ values suggests the presence of considerable out of plane and in plane $\pi$-bonding contribution in M-L $\pi$-bonding. Accordingly, the EPR studies of the copper complexes have provided supportive evidence to the optical and magnetic results.

\subsection{Electronic Spectra and Magnetic Behavior}

The electronic spectra of the $\mathrm{Cu}(\mathrm{II})$ complexes were displayed in Nujol mull and/or DMSO. The electronic spectra show a broad band lie in the 13,551 $17,860 \mathrm{~cm}^{-1}$ range suggesting $\mathrm{d}-\mathrm{d}$ transition $\left({ }^{2} E_{2 g} \rightarrow{ }^{2} T_{2 g}\right)$ in octahedral geometry around the $\mathrm{Cu}^{2+}$ ion [34] [35]. Also, the values of the corrected subnormal magnetic moment of the complexes (2-12) fall in the $0.75-1.24 \mathrm{BM}$ are taken as strong evidence for the existence of polymeric nature [36] [37] and strong $\mathrm{Cu}-\mathrm{Cu}$ interaction. The value of magnetic moment of complex $\left(2, \mathrm{C}_{11} \mathrm{H}_{23} \mathrm{Cl}_{2} \mathrm{~N}_{9} \mathrm{O}_{6} \mathrm{Cu}_{3}\right)$ was found to be $1.95 \mathrm{BM}$. The high value of magnetic moment of complex (2) in comparison to the previous complexes (3-12) in spite of the polymeric nature of this complex, which contains three copper atoms, is due to the absence of any $\mathrm{Cu}-\mathrm{Cu}$ interaction within this complex either in the $x y$ or directions. The data of electronic spectra and magnetic moments are shown in Table 2.

\subsection{TGA Studies}

The amounts of the coordinated solvents and/or the hydrated solvents have been determined in the range $25^{\circ} \mathrm{C}-200^{\circ} \mathrm{C}$. The experimental weight loss values are in good agreement with the calculated values. The TGA curves of the $\mathrm{Cu}^{2+}$ complexes exhibit two different types of weight loss, in the above range, indicating the presence of two types of solvents. The Former in the $50^{\circ} \mathrm{C}-120^{\circ} \mathrm{C}$ range suggesting the presence of hydrated solvents while the latter in the range $125^{\circ} \mathrm{C}$ $200^{\circ} \mathrm{C}$ illustrating the presence of coordinated solvents.

\section{Conclusion}

The new polymeric $\mathrm{Cu}^{2+}$ complexes derived from cyanoacetylhydrazine in dif- 
ferent solvents were characterized by spectral, magnetic and thermal analyses. The different ligands obtained by the promotion of different solvents to the cyano groups were suggested according to the spectral studies. The ligands obtained coordinate in a bidentate manner via the carbonyl and the $\mathrm{NH}_{2}$ groups forming five-membered rings around the copper(II) ion. The results of spectral together with the values of magnetic moments suggest distorted-octahedral geometry around the $\mathrm{Cu}^{2+}$ ion. The Spin-Hamiltonian parameters obtained from the EPR spectra of the complexes in DMSO at low temperature were used to calculate the bonding parameters. DFT calculations illustrate the chemical reactivity and the site selectivity of the molecular systems. Both the energies of ( $E_{\mathrm{HO} о}+$ $\left.E_{\mathrm{LUMO}}\right)$ and band gap ( $\left.E_{\text {номо }}-E_{\mathrm{LUMO}}\right)$ illustrate preemptory the charge-transfer interplay within the molecule, electronegativity, chemical potential, global hardness, global softness and global electrophilicity index are listed.

\section{Conflicts of Interest}

The article is original and unpublished and is not being considered for publication elsewhere. The author declares that he has no conflict of interests that could influence this work.

\section{References}

[1] Rahman, V.P.M., Mukhtar, S., Ansari, W.H. and Lemiere, G. (2005) Synthesis, Stereochemistry and Biological Activity of Some Novel Long Alkyl Chain Substituted Thiazolidin-4-Ones and Thiazan-4-One from 10-Undecenoic Acid Hydrazide. European Journal of Medicinal Chemistry, 40, 173-184. https://doi.org/10.1016/j.ejmech.2004.10.003

[2] Ajani, O.O., Obafemi, C.A., Nwinyi, O.C. and Akinpelu, D.A. (2010) Microwave Assisted Synthesis and Antimicrobial Activity of 2-Quinoxalinone-3-Hydrazone Derivatives. Bioorganic \& Medicinal Chemistry, 18, 214-221. https://doi.org/10.1016/j.bmc.2009.10.064

[3] Bondock, S., Tarhoni, A.E. and Fadda, A.A. (2006) Utility of Cyanoacetic Acid Hydrazide in Heterocyclic Synthesis. Arkivoc, 9, 113-156. https://doi.org/10.3998/ark.5550190.0007.905

[4] Donald, P.R., Seifart, H.I., Parkin, D.P. and van Jaarsveld, P.P. (1994) Hydrazine Production in Children Receiving Isoniazid for the Treatment of Tuberculous Meningitis. Annals of Pharmacotherapy, 28, 1340-1343. https://doi.org/10.1177/106002809402801202

[5] Zheng, L.W., Wu, L.W., Zhao, B.X., Dong, W.L. and Miao, Y.J. (2009) Synthesis of Novel Substituted Pyrazole-5-Carbohydrazide Hydrazone Derivatives and Discovery of a Potent Apoptosis Inducer in A549 Lung Cancer Cells. Bioorganic \& Medi cinal Chemistry, 17, 1957. https://doi.org/10.1016/j.bmc.2009.01.037

[6] Elnagdi, M.H., Elmoghayar, M.R.H. and Elgemeie, G.E.H. (1984) Activated Nitriles in Heterocyclic Synthesis: A New Approach for the Synthesis of Pyridine and Pyridinopyrimidine Derivatives. Synthesis, 11, 970-972. https://doi.org/10.1055/s-1984-31042

[7] Gaber, A.M., El-Gaby, M.S.A., El-Dean, A.M.K., Eyada, H.A. and Al-Kamali, A.S.N. (2004) Synthesis of Novel Polyfunctionally Substituted Thieno[2,3-cPyridazines]. 
Journal of the Chinese Chemical Society, 51, 1325-1331. https://doi.org/10.1002/jccs.200400192

[8] Elagamey, A.G.A., El-Taweel, F.M., Khodeir, M.N.M. and Elnagdi, M.H. (1993) Nitriles in Heterocyclic Synthesis. Teh Reaction of Polyhydric Naphthalenes, 4-Methylcoumarin-3-Carbonitrile, and Akylidenemalononitrile with Methylene Malononitrile. Bulletin of the Chemical Society of Japan, 66, 464-468.

https://doi.org/10.1246/bcsj.66.464

[9] Hussein, A.H.M. (1998) Utility of Cyano Acid Hydrazide in Heterocyclic Chemistry: A New Route for the Synthesis of New 1,2,4-Triazolo[1,5-a]Pyridines and 1,2,4-Triazolo[1,5-a]Isoquinolines. Verlag der Zeitschrift für Naturforschung, 53b, 488-494. https://doi.org/10.1515/znb-1998-0417

[10] Elnagdi, M.H. and Erian, A.W. (1991) New Routes to Polyfunctionally Substituted Pyridine, Pyridopyridine, Quinoline, and Pyridazine Derivatives. Archiv der Pharmazie, 324, 853-858. https://doi.org/10.1002/ardp.2503241106

[11] Gilman, A.G. and Goodman, L.M.S. (1985) The Pharmaceutical Basis of Therapeutics. Macmillan, New York.

[12] Writer, S. and Shaffer, L. (2020) RNA-Based Pesticides Aim to Get around Resistance Problems. Inner Workings, 117, 32823-32826.

https://doi.org/10.1073/pnas.2024033117

[13] De Marinis, R.M., Hoover, J.R.E., Dunn, G.L., Actor, P., Uri, J.V. and Weisbach, J.A. (1975) A New Parenteral Cephalosporin. Sk \& f 59962: 7-Trifluoromethyl Thioacetamido-3-(1-Methyl-1H-Tetrazol-5-Ylthylthiomethyl)-3-Cephem-4-Carboxylic Acid. Chemistry and Structure Activity Relationship. The Journal of Antibiotics, 28, 463-470. https://doi.org/10.7164/antibiotics.28.463

[14] Fahmy, S.M., Badran, A.H. and Elnagdi, M.H.J. (1980) Synthesis of Some New Zopyrazole Dyes. Journal of Chemical Technology \& Biotechnology, 30, 390-395. https://doi.org/10.1002/jctb.503300147

[15] Fahmy, S.M., El-Hosami, M., Elgamal, S. and Elnagdi, M.H. (1982) Dimerised Ethyl Cyanoacetate in Heterocyclic Dye Synthesis. Journal of Chemical Technology \& Biotechnology, 32, 1042-1048. https://doi.org/10.1002/jctb.5030320748

[16] Premkumars, T. and Govindarajan, S. (2002) The Chemistry of Hydrazine Derivatives-Thermal Behavior and Characterisation of Hydrazinium Salts and Metal Hydrazine Complexes of 4,5-Imidazoledicarboxylic Acid. Thermochimica Acta, 386, 35-42. https://doi.org/10.1016/S0040-6031(01)00756-0

[17] Shallaby, A.M., Soliman, M.S., El-Shazely, R.M. and Mostafa, M.M. (1988) Metal Complexes and Metal Promoted Reactions of Cyanoacetyl-Hydrazine (CAH). Synthesis and Reactivity in Inorganic and Metal-Organic Chemistry, 18, 807-821. https://doi.org/10.1080/00945718808060823

[18] El-Shazely, R.M., Shallaby, A.M. and Mostafa, M.M. (1990) Metal Complexes and Metal Promoted Reactions of Salicylaldehyde Cyanoacetyl-Hydrazone in Ethanol. Synthesis and Reactivity in Inorganic and Metal-Organic Chemistry, Part III, 20, 283-299. https://doi.org/10.1080/00945719008048135

[19] El-Shazely, R.M., Soliman, M.S., Shallaby, A.M. and Mostafa, M.M. (1990) Synthesis of New Metal Complexes Derived From Cyanocetyl Hydrazone (SCH) and Its Derivatives with Some Transition Metal Ions in Isopropanol and Tert-Butanol(IV). Synthesis and Reactivity in Inorganic and Metal-Organic Chemistry, 20, 301-318. https://doi.org/10.1080/00945719008048136

[20] Bain, G.A. and Berry, J.F. (2008) Diamagnetic Corrections and Pascal's Constants. 
Journal of Chemical Education, 85, 532-536. https://doi.org/10.1021/ed085p532

[21] Geary, W.J. (1971) The Use of Conductivity Measurements in Organic Solvents for the Characterisation of Coordination Compounds. Coordination Chemistry Reviews, 7, 81-122. https://doi.org/10.1016/S0010-8545(00)80009-0

[22] Mlahi, M.R., Azhari, S.J., El-Asmy, A.A. and Mostafa, M.M. (2015) Comparative Spectroscopic and DFT Calculations of Binary and Ternary Complexes Derived From 4-Allyl-1-(2-Tydroxybenzoyl) Thiosemicarbazide $\left(\mathrm{L}^{1}\right)$ and 2,2'-Dipyridyl. Spectrochimica Acta, 134, 465-472. https://doi.org/10.1016/j.saa.2014.06.098

[23] Linert, W. and Taha, A. (1994) Coordination of Solvent Molecules to Square-Planar Mixed-Ligand Nickel(II) Complexes: A Thermodynamic and Quantum-Mechanical Study. Journal of the Chemical Society, Dalton Transactions, 7, 1091-1095. https://doi.org/10.1039/dt9940001091

[24] Ramachandran, R., Rani, R.M. and Kabilan, S. (2010) Synthesis, Structure and Conformation Alanalysis of 2,4-Diaryl-3-Azabicyclo[3.3.1]Nonan-9-One Thiosemicarbazones and Semicarbazones. Journal of Molecular Structure, 970, 42-50. https://doi.org/10.1016/j.molstruc.2010.02.005

[25] Govindarajan, M., Periandy, S. and Carthigayen, K. (2012) FT-IR and FT-Raman Spectra, Thermodynamical Behavior, HOMO and LUMO, UV, NLO Properties, Computed Frequency Estimation Analysis and Electronic Structure Calculations on $\alpha$-Bromotoluene. Spectrochimica Acta, 97, 411-422. https://doi.org/10.1016/j.saa.2012.06.028

[26] Pearson, R.G. (1989) Absolute Electronegativity and Hardness: Applications to Organic Chemistry. The Journal of Organic Chemistry, 54, 1423-1430. https://doi.org/10.1021/jo00267a034

[27] Padmanabhan, J., Parthasarathi, R., Subramanian, V. and Chattaraj, P. (2007) Electrophilicity-Basbed Charge Transfer Descriptor. The Journal of Physical Chemistry, 111, 1358-1361. https://doi.org/10.1021/jp0649549

[28] Parthasarathi, R., Padmanabhan, J., Sarkar, U., Maiti, B., Subramanian, V. and Chattaraj, P.K. (2003) Toxicity Analysis of Benzidine through Chemical Reactivity and Selectivity Profiles: A DFT Approach. Internet Electronic Journal of Molecular Design, 2, 798-813.

[29] Kivelson, D. and Neiman, R. (1961) ESR Studies on the Bonding in Copper Complexes. The Journal of Chemical Physics, 35, 149-155. https://doi.org/10.1063/1.1731880

[30] Hathway, B.J. and Billing, D.E. (1970) The Electronic Properties and Stereochemistry of Mono-Nuclear Complexes of the Copper(II) Ion. Coordination Chemistry Reviews, 5, 143-207. https://doi.org/10.1016/S0010-8545(00)80135-6

[31] Hathway, B.J. and Tomlinson, A.A.G. (1970) Copper(II) Ammonia Complexes. Coordination Chemistry Reviews, 5, 1-43. https://doi.org/10.1016/S0010-8545(00)80073-9

[32] Zink, J.I. and Drago, R.S. (1972) Interpretation of Electron Spin Resonance Parameters for Transition Metal Complexes. Journal of the American Chemical Society, 4, 4550-4554. https://doi.org/10.1021/ja00768a023

[33] June, V.S.X., Anantharam, R. and Murugesan, R. (1999) The Temperature Dependence of EPR Spectra of $\mathrm{Cu}(\mathrm{II})$-Doped Hexakis(imidazole)Cadmium(II) Perchlorate. Spectrochimica Acta A, 55, 135-142. https://doi.org/10.1016/S1386-1425(98)00174-7

[34] Rao, C.N.R. (1975) Ultraviolet and Visible Spectroscopy. Plenum Press, New York.

[35] Lever, A.B.P. (1968) Inorganic Electronic Spectroscopy. Elsevier, Amsterdam.

[36] Kato, M., Jonassen, KB and Fanning, GC, (1964) Copper(II) Complexes with Sub- 
normal Magnetic Moments. Chemical Reviews, 64, 99-128.

https://doi.org/10.1021/cr60228a003

[37] Mlahi, M.R., Afsah, E.M., Negm, A. and Mostafa, M.M. (2015) Synthesis of 8-Hydroxyquinolium Chloroacetate and Synthesis of Complexes Derived from 8-Hydroxy Quinoline and Characterization, Density Functional Theory and Biological Studies. $A p$ plied Organometallic Chemistry, 29, 200-208. https://doi.org/10.1002/aoc.3265 


\section{Supplementary}

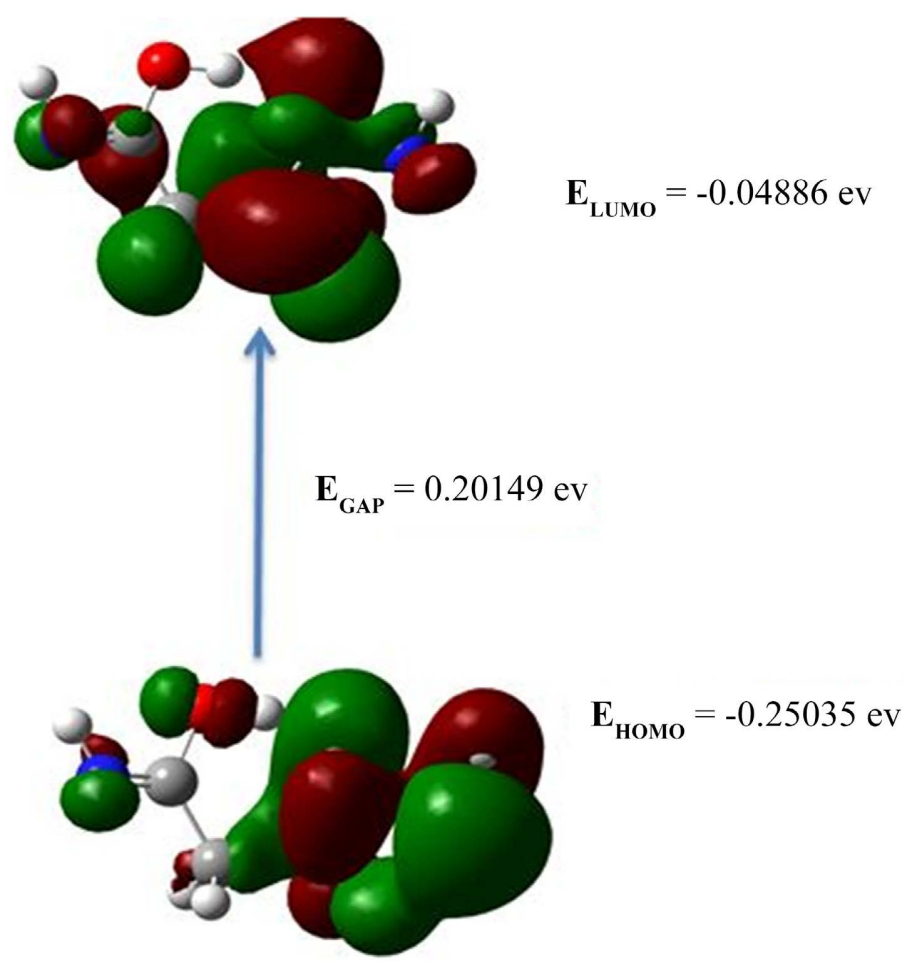

Figure S1. Three-dimensional plots of frontier orbital energies using the DFT method for $\mathrm{L}^{2}$.

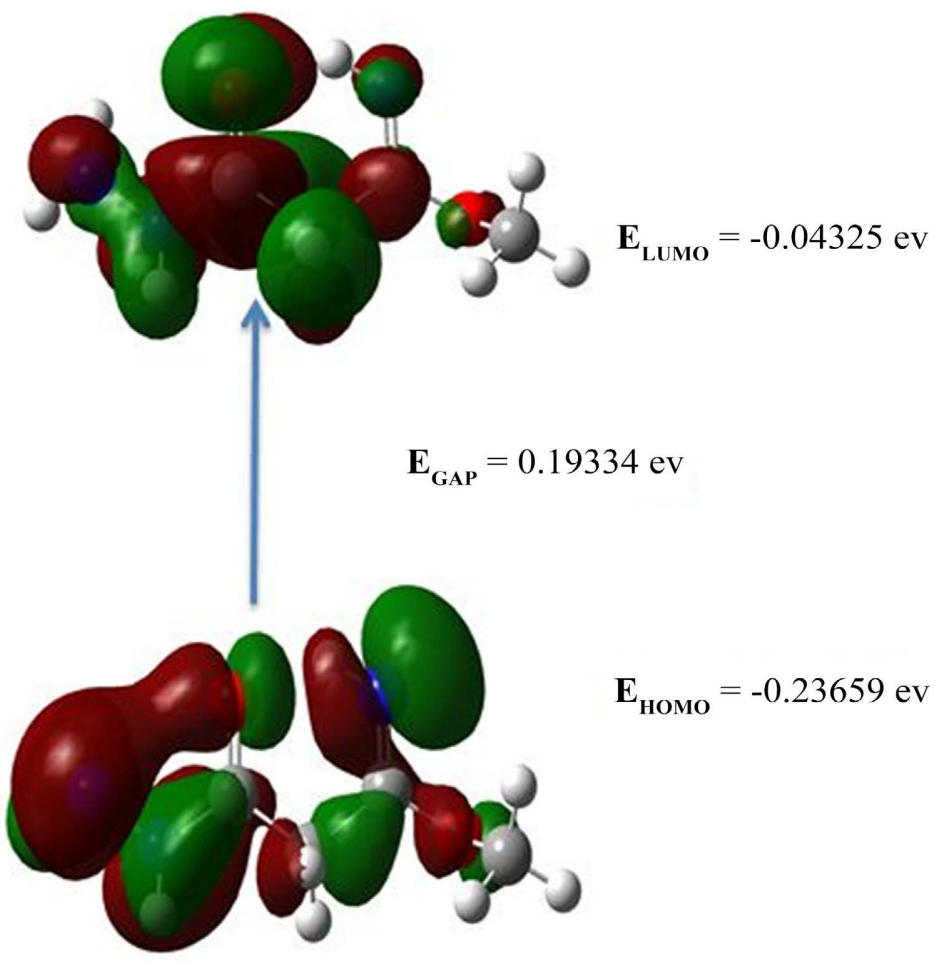

Figure S2. Three-dimensional plots of frontier orbital energies using the DFT method for $\mathrm{L}^{3}$. 


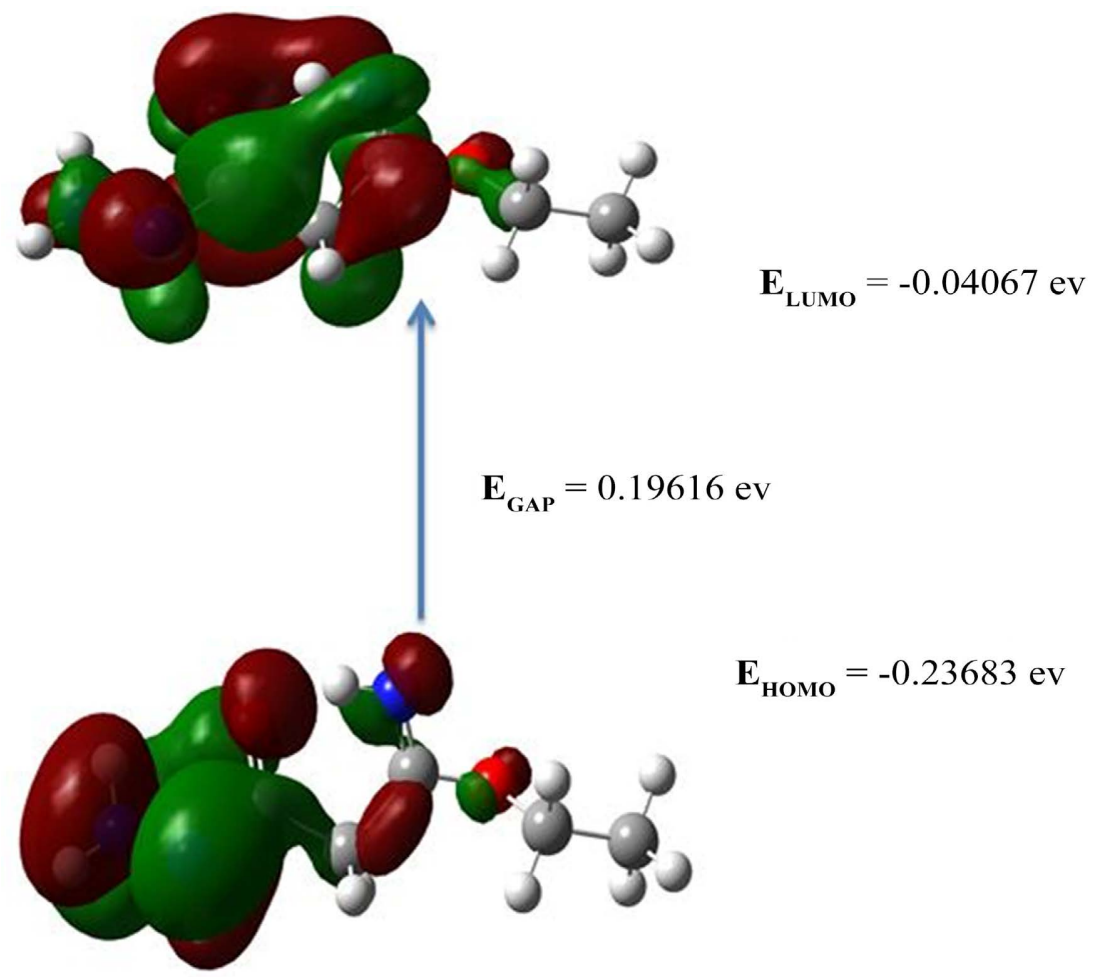

Figure S3. Three-dimensional plots of frontier orbital energies using the DFT method for $\mathrm{L}^{4}$.

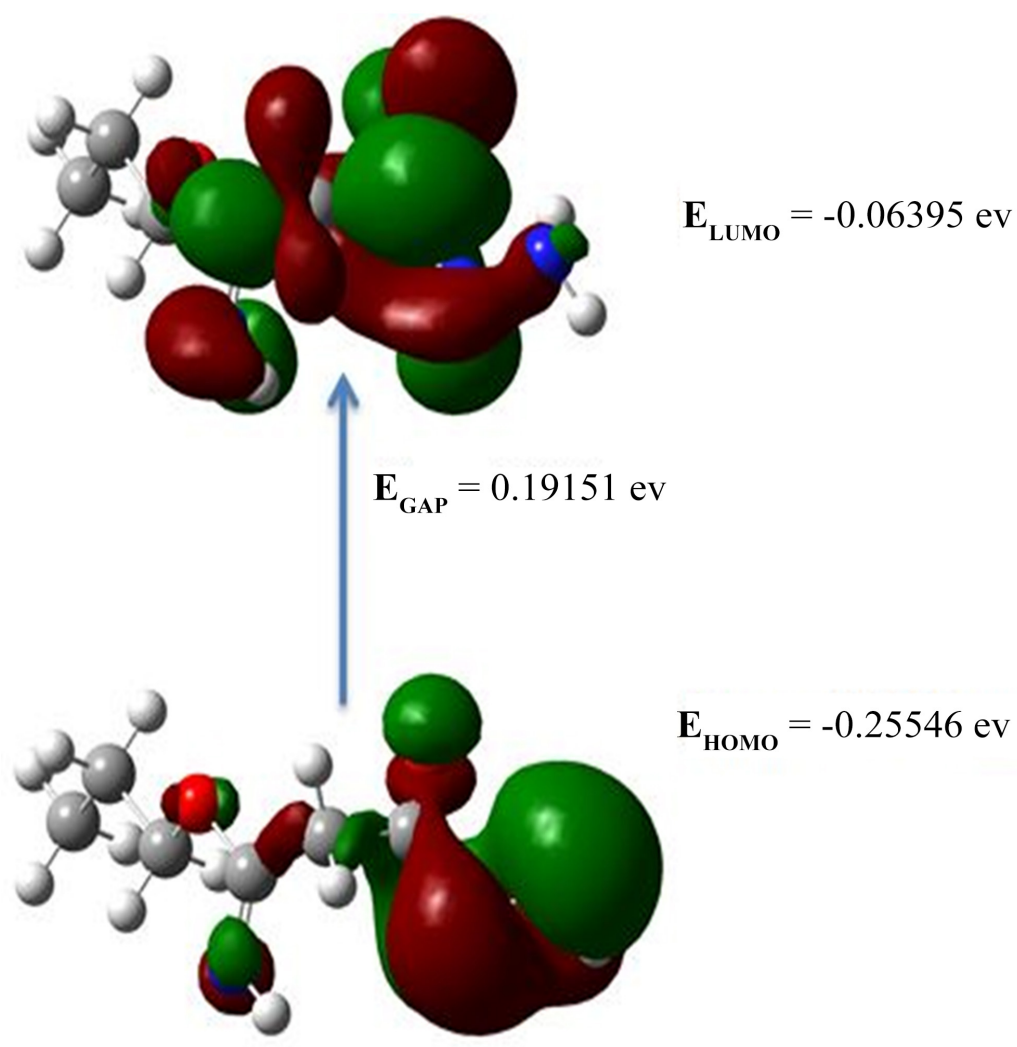

Figure S4. Three-dimensional plots of frontier orbital energies using the DFT method for $\mathrm{L}^{5}$. 


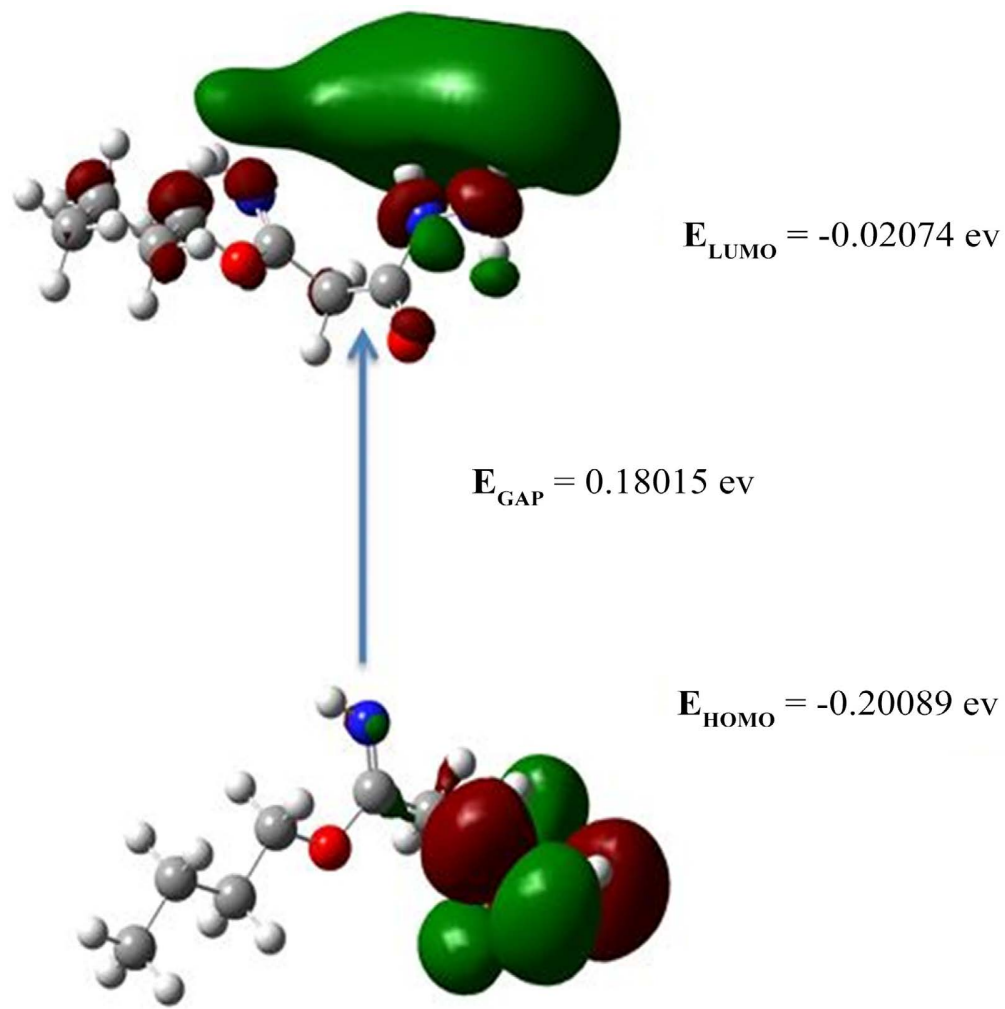

Figure S5. Three-dimensional plots of frontier orbital energies using the DFT method for $\mathrm{L}^{6}$.

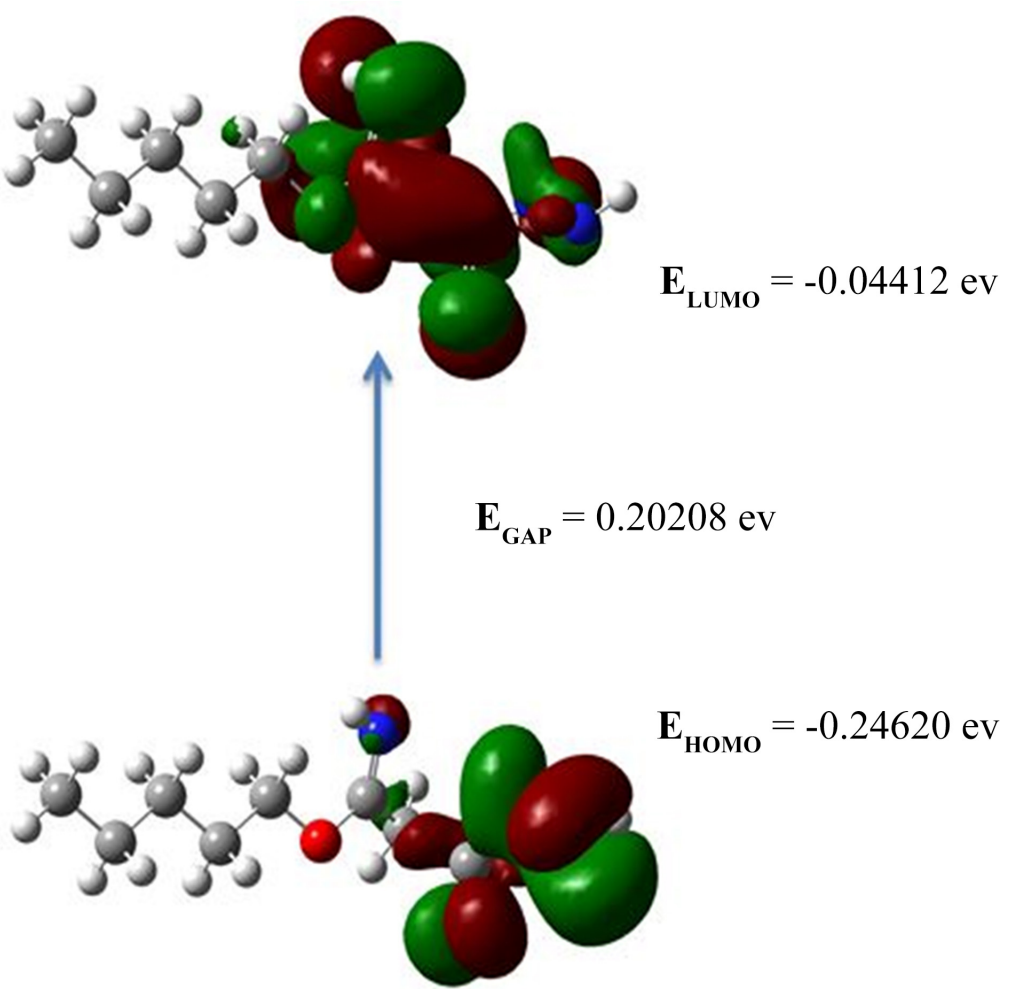

Figure S6. Three-dimensional plots of frontier orbital energies using the DFT method for $\mathrm{L}^{7}$. 